\title{
FOREIGN INVESTMENT LAW IN THE PEOPLE'S REPUBLIC OF CHINA: WHAT TO EXPECT FROM ENTERPRISE ESTABLISHMENT TO DISPUTE RESOLUTION
}

\author{
Jessica Zoe Renwald*
}

\section{INTRODUCTION}

"The future of China is closely linked with that of the whole world."1

Since the opening up of China in $1978^{2}$ by Deng Xiaoping, ${ }^{3}$ China's gross domestic product has grown an "average of $9.5 \%$ a year." According to a recent Economist survey, much of China's growth during the past twenty-five years is due to a significant amount of foreign direct investment (FDI). ${ }^{5}$ Through 2004 , China received a cumulative $\$ 563.8$ billion in foreign direct

* J.D., Indiana University School of Law-Indianapolis, 2006. I would like to thank Professor Frank Emmert, Executive Director of the Center for International and Comparative Law, for his advice and assistance on this Note.

1. Zhonguo Renmin Gongheguo Xianfa [P.R.C. Constitution] pmbl. (1982), http://english.people.com.cn/constitution/constitution.html (last updated Mar. 22, 2004) [hereinafter XIANFA].

2. See William I. Friedman, One Country, Two Systems: The Inherent Conflict Between China's Communist Politics and Capitalist Securities Market, 27 BROOKLYN J. INT'L L. 477, 478 (2002). The Communist Party took control of China's economy in 1949 and turned it into a planned economy. Id. A state-run economy produced "few incentives" for the Chinese to participate in the economy, which led to an "ailing" state-owned sector. Id. In 1978, Deng Xiaoping adopted the "open door" policy, which consisted of several reforms designed to use foreign capital and resources to "speed up" the growth of the Chinese economy. Id.

3. Deng Xiaoping (1904-1997) was the Chairman of the Party's Central Military Commission. See CNN In-Depth Specials, Reformer with an Iron Fist, at http://www.cnn.com/SPECIALS/1999/china.50/inside.china/profiles/deng.xiaoping (n.d.) (last visited Mar. 29, 2006). Deng Xiaoping was one of the leaders in the movement to open China up to foreign investment and a market economy. $I d$.

4. The Real Great Leap Forward, THE ECONOMIST, Sept. 30, 2004, available at http://www.economist.com/displaystory.cfm?story_id=3219418. China's GDP growth is "three times the rate than that in the United States" and is "faster than in any other economy." Id. See also China's Growing Pains, THE ECONOMIST, Aug. 19, 2004, available at http://www.economist.com/displaystory.cfm?story_id=3107157. An Economist poll forecasts growth "this year at $9.2 \%$, and at a still-stellar $7.9 \%$ next year." Id.

5. See generally The Real Great Leap Forward, supra note 4; see also Joshua Kurlantzik, Asia Minor, NEw REPUBLIC, December 26, 2002, at 24. The author notes that "90 percent of foreign-invested businesses in China plan to expand their operations in the next three years." Id. 
investment. $^{6}$ Its large population ${ }^{7}$ and immense commercial opportunities ${ }^{8}$ make China one of the most important, if not the key, destination for foreign direct investment in the world. ${ }^{9}$ The economic potential of the Chinese market is undeniable, ${ }^{10}$ and it has become a magnet for foreign investors. ${ }^{11}$

However, despite China's accession to the World Trade Organization (WTO) in $2001^{12}$ and the rise of various successful FDI vehicles operating within China, foreign investors should be cautioned that the concept of the rule of law has not been fully implemented within China. ${ }^{13}$ Particularly when establishing an enterprise in China or resolving disputes with Chinese entities, the foreign investor needs to be aware of the cultural and structural differences inherent in the Chinese legal system as they pertain to the type of investment enterprise chosen by the foreign investor.

This Note serves as a practical commentary designed to offer information for the medium-sized firm thinking about investing in China for the first time. Part I of this Note will address the current state of the law in China and how the structure of the Chinese government contributes to the sometimes confusing combination of laws for the foreign investor. Part II will discuss several popular forms of foreign direct investment in China and the restrictions and establishment procedures unique to each type. Part III will compare the most popular methods of dispute resolution mechanisms with Chinese entities, focusing on arbitration and litigation and how they affect different types of investment enterprises. Finally, as a result of China's accession to the WTO

6. U.S. DePt of STATe, 2005 Investment Climate Statement-China, available at http://www.state.gov/e/eb/ifd/2005/42000.htm (n.d.) (last visited Mar. 29, 2006) [hereinafter U.S. DEPT OF STATE]. China added " $\$ 64.0$ billion" in the year 2004. Id.

7. See China Population Development and Research Center, at http://www.cpirc.org.cn/en/eindex.htm (updated daily) (last visited Mar. 29, 2006). An estimated 1.3 billion people reside in China. Id.

8. See China's Growing Pains, supra note 4, at 11 . A middle class of approximately 100 million people exists in China, "where none at all existed before." Id.

9. See Karen Halverson, China's WTO Accession: Economic, Legal, and Political Implications, 27 B.C. INT'L \& COMP. L. REV. 319, 320 (2004) (observing that China is "second only to the United States" as a destination for foreign direct investment); see also U.S. DEPT OF STATE, supra note 6. "China has maintained its position as one of the world's top two destinations for foreign direct investment." $l d$.

10. See The Real Great Leap Forward, supra note 4. "China is ... likely one day to overtake America and become the world's number one economy." Id.

11. See generally Sameena Ahmad, Survey: Behind the Mask, THE EconOMIST, Mar. 18, 2004 (describing the current "tidal wave of foreign enthusiasm for China" evidenced by the influx of FDI and rapid growth), available at http://www.economist.com/displayStory.cfm?Story_id=2495113.

12. See generally ChINA Development Gateway, China's Long MaRch INTO THE WTO (July 25, 2003) (detailing the long process begun in 1986 that led to China's accession to the WTO on Dec. 11, 2001), at http://www.chinadaily.com.cn/chinagate/doc/200307/25/content_249150.htm.

13. See generally Peter Howard Corne, Creation and Application of Law in the PRC, 50 AM. J. СомP. L. 369 (2002) (giving a thorough description of the problems still inherent in the Chinese legal system). 
and other developments, many positive reforms have been instituted by the Chinese government. Part IV will offer perspectives on the various changes to the Chinese system and the future outlook for foreign investment in China.

\section{CHINA'S STRUGGLE WITH THE RULE OF LAW}

"The People's Republic of China is a socialist state under the people's democratic dictatorship." 14

China is an extremely diverse nation ${ }^{15}$ divided into twenty-three provinces. ${ }^{16}$ Each province is then subdivided into prefectures, counties, and cities. $^{17}$ In addition, each county may also be subdivided into townships, "national minority townships," or towns. ${ }^{18}$ Although diverse and with many smaller units of government, the Chinese regime is a "unitary system" with all authority coming from the central government. ${ }^{19}$ The Chinese Constitution (Constitution) identifies China as a "socialist state under the people's democratic dictatorship" 20 and applies the principle of "democratic centralism."21 These phrases perhaps seem odd to western notions, but they exemplify the concepts upon which the law in China is based. ${ }^{22}$

Since the Communist Revolution in $1949,{ }^{23}$ law in The People's Republic of China (PRC or China) has become an "ideological instrument of politics."24 For example, the laws in China are plagued by problems of "vagueness," "omissions," and "general "catch-all' provisions." 25 The less certainty and detail in the laws, the better the Chinese government will be able to respond to

14. XIANFA art. 1.

15. See Dr. Jianfu Chen, Dealing With Local Law In China, 3 CHINA L. UPdATE 3 (2000). A 1990 census revealed that there are fifty-six ethnic nationalities in China. Id. Aside from the Han Chinese majority, the fifty-five different ethnic minorities make up about 91.2 million people of the approximately 1.3 billion people in China. Id.

16. See id.

17. Id.

18. Id.

19. Corne, supra note 13 , at 369 . "The PRC is a unitary, not a federated state- state power being an indivisible whole." Id.

20. XIANFA art. 1. See also Mao Tse-tung, On the People's Democratic Dictatorship, in SELECTED WORKS OF MAO TSE-TUNG (1969).

21. XIANFA art. 3.

22. See generally Eric Orts, The Rule of Law in China, 34 VAND. J. TRANSNAT'L L 43 (2001). The Chinese legal system followed the Marxist thought that the Communist Party should have "absolute control" over the "organs of the state." Id. at 57.

23. See supra note 2.

24. Orts, supra note 22 , at 57.

25. Come, supra note 13, at 374. See, e.g., Wholly Foreign Owned Enterprise Law of the People's Republic of China (Apr. 12, 1986), http://www.chinajnbook.com/business/wfoenla.htm [hereinafter WFOE Law]. Article 5 states, "Under special circumstances, when public interest requires, enterprises with foreign capital may be requisitioned by legal procedures...." Id. The law provides no definition of what "public interest" requires. Id. 
"rapid political and economic change."26 Ambiguity leads to greater flexibility in interpretation and a "wide variation in application."27 Indeed, "short-term flexibility" in lawmaking seems to be preferred over long-term policies. ${ }^{28}$

\section{A. Primary Sources of $\mathrm{Law}^{29}$}

The Chinese central government comprises several different levels of law-making bodies. The National People's Congress (NPC) operates as the most powerful legislative body in the central government of China. ${ }^{30}$ Responsibilities of the NPC include supervising the enforcement of the Constitution, amending the Constitution, enacting laws, deciding "questions of war and peace," and other important powers. ${ }^{31}$ The NPC elects the President of the PRC, who may promulgate laws, remove other heads of departments, and

26. Corne, supra note 13, at 375. "The Chinese legal system is thus, in essence, as fluid and changeable as the economy ... which it is supposed to regulate." Id.

27. Id. at 374. There is no practice of striking down a law on the "basis of uncertainty." Id. at 375 .

28. Id. at 375 .

29. See generally Chen, supra note 15 , at 2 (illustrating the "hierarchy of law" with a chart).

30. XIANFA art. 57. This article states, "The National People's Congress of the People's Republic of China is the highest organ of state power." Id.

31. Id. art. 62. China's constitution delineates the following powers to the NPC:

(1) To amend the Constitution; (2) To supervise the enforcement of the Constitution; (3) To enact and amend basic statutes concerning criminal offences, civil affairs, the state organs and other matters; (4) To elect the President and the Vice-President of the People's Republic of China (previously translated as Chairman and Vice-Chairman of the People's Republic of China--translator's note.); (5) To decide on the choice of the Premier of the State Council upon nomination by the President of the People's Republic of China, and to decide on the choice of the Vice-Premiers, State Councillors [sic], Ministers in charge of Ministries or Commissions and the Auditor-General and the Secretary-General of the State Council upon nomination by the Premier; (6) To elect the Chairman of the Central Military Commission and, upon his nomination, to decide on the choice of the other members of the Central Military Commission; (7) To elect the President of the Supreme People's Court; (8) To elect the Procurator-General of the Supreme People's Procuratorate; (9) To examine and approve the plan for national economic and social development and the reports on its implementation; (10) To examine and approve the state budget and the report on its implementation; (11) To alter or annul inappropriate decisions of the Standing Committee of the National People's Congress; (12) To approve the establishment of provinces, autonomous regions, and municipalities directly under the Central Government; (13) To decide on the establishment of special administrative regions and the systems to be instituted there; (14) To decide on questions of war and peace; and (15) To exercise such other functions and powers as the highest organ of state power should exercise. 
receive foreign diplomats. ${ }^{32}$ The NPC also elects the President of the Supreme People's Court and all other major heads of departments. ${ }^{33}$

The approximately 3,000-member NPC meets once a year for two to three week periods. ${ }^{34}$ The members, or delegates, are not directly elected by China's citizens; delegates are chosen by the people's congresses at the provincial level from an NPC-approved list of nominated candidates in each local area. ${ }^{35}$ The actual result is that the delegates are members of the Chinese Communist Party (CCP) and do not reflect the "views and aspirations of any popular constituency." 36 Further, CCP membership is often "an essential requirement" to obtaining any influential role in the government. ${ }^{37}$

In addition to the NPC, the Chinese law-making branch also includes the NPC Standing Committee, which is the permanent body of the NPC. ${ }^{38}$ The NPC Standing Committee is composed of about 200 members $^{39}$ appointed by the $\mathrm{NPC}^{40}$ and meets regularly during the year when the NPC is not in session. ${ }^{41}$ The NPC Standing Committee, like the NPC, may enact laws; however, they must be other than the "basic" by the National People's Congress."43 Importantly, when the NPC or its Standing Committee makes laws, there is no public involvement or debate in the drafting process. ${ }^{44}$

Another primary source of law in China is the Supreme People's Court (SPC), ${ }^{45}$ which is the "highest judicial organ" in China. ${ }^{46}$ The court system in

32. Id. art. 80. The President's duties are carried out "in pursuance of decisions of the National People's Congress and its Standing Committee." Id.

33. Id. art. 62.

34. James M. Zimmerman, Legislating, the Judiciary, and Lawyers in China, in CHINA LAW DESKBOOK 27-28 (1999).

35. See Corne, supra note 13 , at 379.

36. Id. See also Orts, supra note 22 , at 66 . "In practice, the formal legal and political structures very often remain subject to the will of the Communist Party leadership." Id.

37. See Zimmerman, supra note 34 , at 31 . The NPC is a "rubber-stamping body that unquestioningly follows the party line while the annual meetings and media coverage are intended to create the illusion of democracy." Id.

38. XIANFA art. 57. "The National People's Congress of the People's Republic of China is the highest organ of state power. Its permanent body is the Standing Committee of the National People's Congress." Id.

39. See Zimmerman, supra note 34 , at 29.

40. XIANFA art. 65. "The National People's Congress elects, and has the power to recall, all those on its Standing Committee." Id.

41. See generally Zimmerman, supra note 34, at 28-30 (describing the NPC and its Standing Committee and the various functions of each).

42. XIANFA art. 62. The duties of the NPC include enacting and amending "basic statutes concerning criminal offences, civil affairs, the state organs and other matters." Id.

43. Id. art. 67. The duties of the NPC Standing Committee include enacting and amending "statutes with the exception of those which should be enacted by the National People's Congress." Id.

44. See Zimmerman, supra note 34 , at 29.

45. See generally Chen, supra note 15 , at 2 (illustrating the primary and secondary sources of law with a chart). 
China is divided into four levels: "(1) the Supreme People's Court is at the national level; (2) the higher people's court at the provincial level; (3) the intermediate people's court at the municipal level; and (4) basic people's court at the county level."47 Although it is the weakest organ in the government, ${ }^{48}$ the powers of the SPC include supervising the many local people's courts operating throughout the provinces. ${ }^{49}$ SPC interpretations of law are binding on the lower courts, ${ }^{50}$ but they are restricted to "clarifying and strengthening laws," as the NPC and the Standing Committee are responsible for interpreting statutes and the Constitution. ${ }^{51}$ China does not have a system of judicial precedent, and the courts do not have the power to interpret the law" since the SPC is "responsible to the National People's Congress and its Standing Committee."53 Furthermore, since CCP membership is often very important in attaining positions within the NPC and its Standing Committee, ${ }^{54}$ the CCP has substantial influence over the courts. $^{55}$

46. XIANFA art. 127. "The Supreme People's Court is the highest judicial organ." Id.

47. Zimmerman, supra note 34 , at 38 .

48. See M. Ulric Killion, Post-WTO China and Independent Judicial Review, 26 Hous. J. INT'L L. 507, 535 (2004). “[T] he Supreme People's Court-the highest judicial organ-is, in constitutional text, practice, and power subordinate to both the NPC and State Council in judicial interpretive powers." Id.

49. XIANFA art. 127. "The Supreme People's Court supervises the administration of justice by the local people's courts at different levels and by the special people's courts; people's courts at higher levels supervise the administration of justice by those at lower levels." Id.

50. See Email from David Yiping Lu, Senior Judge of the People's Republic of China, Professor of the State College of Judges of China, Advisor to the Center for Comparative and International Law at Indiana University (Feb. 4, 2005, 09:54:31 EST) (on file with author) (noting that the interpretations of the SPC should be used by the people's courts at the trial level).

51. Corne, supra note 13 , at 409. Indeed, the NPC Standing Committee has the power to "annul or amend" SPC interpretations of law that are not in the spirit with the "original meaning of the law." Id. at 424; see also XIANFA art. 67. The NPC Standing Committee may "interpret the Constitution and supervise its enforcement." Id.

52. See Chris X. Lin, A Quiet Revolution: An Overview of China's Judicial Reform, 4 ASIAN-PAC. L. \& POL'Y J. 180, 195 (2003) (describing, in part, that the courts "do not have the power to apply the Constitution").

53. XIANFA art. 128. "The Supreme People's Court is responsible to the National People's Congress and its Standing Committee." Id. But see id. art. 126. Article 128 seems to contradict Article 126, which says, in part, that the people's courts shall "exercise judicial power independently and are not subject to interference by administrative organs, public organizations or individuals." Id.

54. See supra note 34.

55. See generally Lin, supra note 52, at 195-214 (describing, in part, the relationship between the Communist Party and the courts); see also SETH GARZ, THE CARNEGIE ENDOWMENT FOR INT'L PEACE, THE CHINESE COMMUNIST PARTY'S LEADERSHIP AND JUDICIAL INDEPENDENCE (Oct. 29, 2003), at http://www.carnegieendowment.org/events/index.cfm?fa=eventDetail\&id=650. Professor Li Yayun, a scholar and legal practitioner in China, gives examples of Communist Party involvement in the legal system: (1) Communist Party "committees" handle and "even decide[] some specific cases"; (2) "local CCP committees may appoint, dismiss, or rotate" leaders in the "courts"; and (3) Communist Party members are "likely to intervene" in cases that "affect local economic interests" "on behalf of the local government." Id. 


\section{B. Secondary Sources of Law ${ }^{56}$}

Secondary law-making bodies also exist in China, which may create confusion for the foreign investor. ${ }^{57}$ The State Council, an administrative body elected by the NPC, oversees the many "ministries, bureaus, commissions, and local governments." 58 The State Council has the power to pass "administrative rules and regulations," other statutes, but higher than local ordinances and regulations." Council is considered both "legislative and executive" in its power. Additionally, the many ministries, bureaus, and other administrative bodies supervised by the State Council are also granted certain law-making powers and may issue compulsory directives and rules. ${ }^{62}$ The State Council may also authorize "tentative" or "interim" regulations ${ }^{63}$ designed to control local situations when no current regulating legislation exists. ${ }^{64}$ Later, after "sufficient experience" has been accumulated, the "quasi-law[s]" enacted by the State Council will be drafted into law by the NPC. ${ }^{65}$ The regulations promulgated by the State Council or the other administrative bodies are not subject to interpretation by the judicial organs; instead, only the State Council may interpret these enactments. ${ }^{66}$

At the local level of administration, there are people's congresses and standing committees established throughout the "provincial, 'quite big city,' county . . . township/village and hamlet[s]" of China. ${ }^{67}$ The local people's chart).

56. See generally Chen, supra note 15 , at 2 (illustrating the "hierarchy of law" with a

57. See id. at 3 (noting the division of state powers and functions is "not always" clear between the various state organs).

58. Zimmerman, supra note 34 , at 31 .

59. XIANFA art. 89(1). "To adopt administrative measures, enact administrative rules and regulations and issue decisions and orders in accordance with the Constitution and the statutes." Id.

60. China Internet Information Center, Creation of Regulations by the State Council and Its Departments (Sept. 28, 2003), http://www.china.org.cn/english/kuaixun/76340.htm [hereinafter China Information Center].

61. Corne, supra note 13, at 381 . The State Council may "issue decisions ... and orders ... in accordance with the Constitution and statutes." Id.

62. See Chen, supra note 15 , at 3. See also China Information Center, supra note 60. "The State Council has several dozen ministries, commissions, and other directly affiliated organs. Departmental regulation making is a general term for regulation making by the several dozen bodies under the State Council. The rules and regulations they make have equal validity." Id.

63. Corne, supra note 13 , at 382 .

64. Id.

65. Id.

66. See Email from David Yiping Lu, Senior Judge of the People's Republic of China, Professor of the State College of Judges of China, Advisor to the Center for Comparative and International Law at Indiana University (Feb. 4, 2005, 09:54:31) (on file with author).

67. Corne, supra note 13, at 388; see also XIANFA art. 95. "People's congresses and people's governments are established in provinces, municipalities directly under the Central 
congresses and standing committees "ensure the observance and implementation of the Constitution." ${ }^{68}$ With the approval of the State Council, they may adopt certain laws to promote local economic and cultural growth. ${ }^{69}$ The rules and regulations enacted by local people's congresses at the provincial and quite big city level are considered law. ${ }^{70}$ These congresses may also issue supplemental "decisions" and "resolutions" that can be used as the "basis of legal decision[s]." "71

However, the "resolutions . . . orders . . . circulars . . notices . . and opinions" issued below the provincial and quite big city levels "lack legal status" ${ }^{172}$ and serve only administrative purposes. ${ }^{73}$ Complicating matters for the foreign investor, each administrative body governed by the State Council has lower units in all the local provinces, which may also issue merely normative rules to be applied "in the course of their local operations."

The laws enacted by the local people's congresses, standing committees, and other administrative bodies may not be in conflict with any law enacted by the NPC or in violation of the Constitution. ${ }^{75}$ The Constitution, however, is unclear about the line between the local directives and the central laws. ${ }^{76}$ The State Council and the other departments do have the power to revoke unsuitable or inconsistent legislation passed by the local governments ${ }^{77}$ but these laws are still often in conflict with higher level Chinese laws, as that power is seldom used. $^{78}$

Government, counties, cities, municipal districts, townships, nationality townships and towns." ld.

68. XIANFA art. 99.

69. Id. "Local people's congresses at different levels ensure the observance and implementation of the Constitution" as well as the "statutes and the administrative rules and regulations in their respective administrative areas." Id.

70. Corne, supra note 13 , at 389.

71. Id.; see also Chen, supra note 15 , at 4 .

72. Corne, supra note 13, at 391 ; see also Chen, supra note 15, at 4. "Legislative powers are only granted to people's congresses and their standing committees at the level of province." Id.

73. Corne, supra note 13, at 392 ; see also Chen, supra note 15 , at 4 . Even though the enactments issued by the governments below the provincial level are only "policy," they are called "local rules." Id. These rules are often "overturned as a matter of policy" without "legislative process." Id.

74. See Corne, supra note 13 , at 391.

75. XIANFA art. 100. "The people's congresses of provinces and municipalities directly under the Central Government, and their standing committees, may adopt local regulations, which must not contravene the Constitution." Id; see also Cao Jianming, WTO and the Rule of Law in China, 16 TEMP. INT'L \& COMP. L.J. 379, 388 (2002). “All laws, regulations, decisions, and administrative policies made and implemented by each locality and governmental department that relate to foreign trade and economic cooperation should be in conformity with national laws and regulations." Id.

76. XIANFA art. 99. The local nules are to be issued "[w]ithin the limits of their authority." Id.; see also Chen, supra note 15, at 3 . There is "hardly any ascertainable principles to delimit the boundary of legislative power between the central and local authorities. The Constitution has little to say about this." Id.

77. See Corne, supra note 13, at 370-71.

78. See id., at 370-71; see also Chen, supra note 15 , at 3 . It is "commonplace" that the 
Due to the many sources of law, issuing departments, and conflicts of law, a certain amount of confusion is inevitable. ${ }^{79}$ Therefore, recognizing which enactments have legal status can be a problem for the foreign investor. ${ }^{80}$ In order to ensure that a particular regulation is not just "policy" and has the force of law, ${ }^{81}$ one solution is to make sure the issuing authority is above the county level. ${ }^{82}$ It is important to note that it is the "authority which issue[s]" the laws that gives them validity and not the "designation of the rules." foreign investor should keep this basic understanding in mind when seeking to establish an enterprise in China.

\section{FOREIGN INVESTMENT IN CHINA}

Even before China's accession to the WTO, several popular FDI vehicles operated in China to infuse the country with capital, but the laws and regulations governing foreign investment were not codified and thus discouraged foreign investment. ${ }^{84}$ Since the open-door policy in the late $1970 \mathrm{~s},{ }^{85}$ the NPC and its Standing Committee set out to create an environment that would encourage more foreign investment by enacting numerous laws that protect the "lawful rights and interest of those enterprises."

"rules and regulations" issued by the "central and local authorities" to be in conflict. Id. However, "[t]he Constitution and other organic laws do create some mechanisms for dealing with the conflict of laws, such as . . . filing with the . . . State Council which would allow superior authorities to examine possible conflict[,] . . . [but] these mechanisms . . . are rarely used." Id.

79. See Chen, supra note 15 , at 5. "[S]ome Chinese scholars claim that inconsistency exists in every single piece of legislation." $l d$.

80. Come, supra note 13 , at 393. The documents issued at the lower local levels are "often expressed in a form complete with chapters and articles," making them "almost indistinguishable" from the legally binding rules and regulations. Id. In addition, the "titles" used by these non-legally binding documents are "readily used by local governments in their own enactments," making them very difficult to identify. Id.

81. See Corne, supra note 13 , at 392 . In order to illustrate the sometimes confusing state of the laws in China, the author gives an example of a published provision entitled, "Operational Rules for the Approval and Registration of Sino-foreign Non-legal Person Cooperative Joint Ventures" issued by the "Shanghai Foreign Investment Working Committee and the Shanghai Administration for Industry and Commerce." Id. The document has no legal status "before a court of law." Id. The document must not be approved only by the "local functional departments" but by the "Shanghai Municipal People's Government" to be valid. Id.

82. See Chen, supra note 15, at 3-4. "Level of authority" and "category of law" are important guides in determining whether or not the law has any legal status. $1 d$. Any law issued below the "province level" will not have legal status. Id.

83. Chen, supra note 15 , at 4.

84. See George O. White III, Foreigners at the Gate: Sweeping Revolutionary Changes on the Central Kingdom's Landscape-Foreign Direct Investment Regulations \& Dispute Resolution Mechanisms in the People's Republic of China, 3 RicH. J. GLoBAL L. \& Bus. 95,98 (2003) (describing the "unfriendly FDI environment" and the "inconsistent rulings, opaque operations, inefficiency, confusion, and lack of predictability") [hereinafter FDI Regulations \& Dispute Resolution Mechanisms].

85. See supra notes 2 and 3.

86. See FDI Regulations \& Dispute Resolution Mechanisms, supra note 84, at 103; see 
groups of foreign investment vehicles in China are the foreign-investment enterprise (FIE) and the foreign enterprise. ${ }^{87}$ Each group has specific implications for the foreign investor in terms of establishment procedures and tax implications.

\section{A. Common Foreign-Invested Enterprises}

The FIE is a foreign direct investment vehicle that is considered a "Chinese legal person" by the NPC ${ }^{88}$ despite the fact that a high percentage of the enterprise may be invested with foreign capital. ${ }^{89}$ These types of FDI vehicles are designed to encourage the transfer of advanced foreign technology to Chinese companies needing modernization. ${ }^{90}$ Generally, to be classified as a FIE, the foreign partner's capital investment may not be lower than twenty-five percent, but "there is no upper limit." The most widespread FIEs in China include joint ventures such as the equity joint venture and the cooperative joint venture, which both require one or more Chinese partners in the operation. ${ }^{92}$ The foreign and Chinese partners in an equity joint venture share the profits and losses on a "pro rata basis." 93 The investors hold no stock in this type of business operation, but instead hold equity interests. ${ }^{94}$ Cooperative joint venture partners, on the other hand, may apportion the profits and losses in any manner they agree upon. ${ }^{95}$ This leads to "creative structuring," and it allows

also WFOE Law art. 1. Article 1 states the relevant law for foreign enterprises:

With a view to expanding economic cooperation and technical exchange with foreign countries and promoting the development of China's national economy, the People's Republic of China permits foreign enterprises, other foreign economic organizations and individuals to set up enterprises with foreign capital

Id. in China and protects the lawful rights and interests of such enterprises.

87. See generally JoNes DAY, INVESTMENT IN THE PEOPLE's REPUBLIC OF CHINA, MONDAQ BUSINESS BRIEFING (Oct. - 11, 2004), http://www.mondaq. com/article.asp?articleid=28935\&searchresults $=1$.

88. Regulations for the Implementation of the Law of the People's Republic of China on Joint Ventures Using Chinese and Foreign Investment (Sept. 20, 1983), http://www.novexcn.com/jv_use_chin_for_invest.html [hereinafter FIE Implementing Regulations]. Article Two states that "[j]oint ventures using Chinese and foreign investment ... established within China's territory in accordance with the Law on Chinese-Foreign Joint Ventures are Chinese legal persons and are subject to the jurisdiction and protection of Chinese law." Id.

89. See generally George O. White III, Enter the Dragon: Foreign Direct Investment Laws and Policies in the P.R.C., 29 N.C. J. INT'L L. \& COM. REG. 35, 36-39 (2003) [hereinafter FDI Laws and Policies].

90. Randall Peerenboom \& Shirley Xu, Wholly Foreign-Owned Enterprises, in 1 DoING BUSINESS IN CHINA II-3.1-3.25, 3.01 (2000).

91. Clark T. Randt, Joint Ventures, in 1 DoING BusINESS IN CHINA II, § 2.04 [3] (2000).

92. See generally id. \$ 2.02 .

93. See id. § 2.04 [3].

94. See JonEs DAY, supra note 87, at 3.3.

95. See Randt, supra note $91, \$ 2.04[3]$. 
the foreign investor to arrange to receive a higher portion of the profit even though it may not have a controlling stake in the operation. ${ }^{96}$

Having a local partner in the enterprise can be beneficial in that there is less capital required from the foreign partner, the Chinese partner brings in valuable assets, ${ }^{97}$ and, as a result, some of the start-up costs can be reduced. ${ }^{98}$ Distrust, and even "bias," against foreigners by local authorities can be further reasons to rely on Chinese partners and invest in an equity joint venture or cooperative joint venture when entering the market. ${ }^{99}$ However, the most important advantage ${ }^{100}$ for a foreign investor is the connections ${ }^{101}$ the Chinese partner has with the community and the valuable assistance provided in dealing with the "multi-headed P.R.C. bureaucracy,"102 which is comprised of the many contradictions and irregularities between the local and the central or provincial level government authorities. ${ }^{103}$

In 1986, the NPC promulgated the Wholly Foreign Owned Enterprise Law of the People's Republic of China. ${ }^{104}$ This law governs enterprises within China with all the capital exclusively provided by foreign investors. ${ }^{105}$ This

96. JONES DAY, supra note 87 , at 3.4 .

97. Randt, supra note $91, \S 2.04$ [3]. "The Chinese partners to a joint venture usually contribute cash . . . rights to use land, existing buildings and structures, and Chinesemanufactured machinery and equipment." Id. But see Peerenboom \& Xu, supra note $90, \S$ 3.02[2](b). The benefits of the Chinese partner often turn out to be "illusory" and the "'assets' . . run-down buildings and out-dated equipment." Id. § 3.02[2](b)(5).

98. See Peerenboom \& Xu, supra note $90, \S 3.02[2](a)(4)$.

99. Michele Lee, Note and Comment, Franchising in China: Legal Challenges When First Entering the Chinese Market, 19 AM. U. INT'L L. REV. 949, 975 (2004). The author notes that, especially for WFOEs, "historical bias against foreigners and large corporations can prove to be heavy burdens for a company entering the Chinese market." Id.

100. See FDI Laws and Policies, supra note 89, at 52.

101. Id.

102. Peerenboom \& Xu, supra note $90, \S 3.02[2]$ (a)(2); see also Chen, supra note 15 , at 3 . "The multiple legislative authorities with no clear division of powers has now produced many inconsistencies and conflicts among Chinese laws." Id.

103. See Chen, supra note 15, at 3-4; see also, e.g., Tim Cussold, Mr. China 85-86 (2004). A first-hand account of an English foreign investor's experience in trying to set up a FIE illustrates some of the potential frustration:

Once the deal was struck, the contracts had to be approved by the government... but the regulations were confusing; even [the Chinese partner] seemed vague about the details . . . . [I]t seemed as if the people on the inside didn't really understand the rules either .... There was a maze of confusing regulations requiring accountant's certificates, tax registrations and valuation reports before the joint ventures could be approved. Many government officials didn't have a clue how even to start working their way through the labyrinth and whenever we asked what to do, each one gave a different answer.

Id.

104. See WFOE Law.

105. Id. Wholly foreign owned enterprises are those "enterprises established in China by foreign investors, exclusively with their own capital, in accordance with relevant Chinese laws. The term does not include branches set up in China by foreign enterprises and other foreign economic organizations." Id. 
popular FIE, called the wholly foreign-owned enterprise (WFOE), allows the foreign investor to own up to $100 \%$ of the enterprise, ${ }^{106}$ although it is still considered a Chinese legal person. ${ }^{107}$ An important goal for the Chinese government in promulgating this type of FIE is the hope that foreign investors will be encouraged to bring in advanced technology and, in turn, develop China's national economy. ${ }^{108}$ Some of the clear advantages of the WFOE over the joint venture types of investments include faster establishment, ${ }^{109}$ direct management control over the enterprise, ${ }^{110}$ technology protection, ${ }^{111}$ and increased profit. ${ }^{12}$

Conversely, the absence of a local Chinese partner can be intimidating. ${ }^{113}$ For example, local relationships may influence the approval process for the WFOE as well as affect "access to land, market sectors, raw materials and distribution networks." 114 In addition, since the nature of the WFOE makes it harder for Chinese authorities to regulate them, the application and approval process must undergo stricter scrutiny. ${ }^{115}$ Despite the downside of not having a local partner to help navigate the sometimes confusing local customs and business practices, ${ }^{116}$ the attraction of the WFOE is inescapable, and the WFOE is now the future of FDI in China. ${ }^{117}$

106. See FDI Laws and Policies, supra note 89, at 38.

107. WFOE Law art. 8. "An enterprise with foreign capital which meets the conditions for being considered a legal person under Chinese law shall acquire the status of a Chinese legal person, in accordance with the law." Id.

108. See id. art. 1. Article 1 provides that in order to expand "economic cooperation and technical exchanges with foreign countries and promote the development of China's national economy," enterprises with $100 \%$ foreign capital will be permitted within China. Id.

109. Peerenboom \& Xu, supra note $90, \& 3.02[2](b)(1)$. The authors note that, "negotiating a joint venture contract ... in China is often time-consuming, expensive and frustrating. Without a joint venture partner to deal with, preparation of the documents required for approval . . . is much simpler." Id.

110. Id. $\$ 3.02[2](\mathrm{b})(2)$. "The differences in management styles, corporate culture, and fundamental goals often result in tension, conflict and in some cases deadlock and inability to continue operations." Id.

111. Id. \$3.02[2](b)(4); see also FDl Laws and Policies, supra note 89, at 40. It has become "extremely controversial and quite problematic" for foreign investors to allow the Chinese partners "access to all pertinent documentation regarding ... industrial property and know-how." Id.

112. Peerenboom \& Xu, supra note $90, \S 3.02[2](\mathrm{b})(5)$. "[T]here is no need to share profits with a joint venture partner." $I d$.

113. See JONES DAY, supra note 87, at 3.2 (noting that for foreign investors "without experience in China," the establishment of the WFOE can be "daunting").

114. Id.

115. See FDI Laws and Policies, supra note 89, at 43. "Because there is not much of a mechanism for regulatory supervision by governmental authorities once the WFOE has been approved[,] . . [t]his form of investment vehicle must go through a stricter form of approval process." Id.

116. See Lee, supra note 99 , at 976 . The author notes "the value of the liaison's understanding of the regional cultural mores should not be underestimated. The combination of local cultural awareness and an understanding of common business practices, allows the foreign 


\section{FIE Establishment}

The first step in establishing a FIE is for the foreign investor to apply to the local government authority. ${ }^{118}$ For both joint ventures and WFOEs, the application procedures are similar. The foreign investor must list the following: (1) the purpose and scale of the operation; (2) what will be produced or manufactured and what types of technology and equipment will be used; (3) what percentage of the output will be overseas compared to the domestic market; (4) land area requirements; and (5) what infrastructure requirements are necessary for the enterprise to stay viable. ${ }^{19}$ The "safest and most conducive way" to gain approval from Chinese authorities for the FIE is to specifically mention on the application that the investment project will aid in the development of the Chinese economy, help to "create an ecologically sustainable development," use "high technology and equipment," and that there are plans to export the "majority of all the products produced in China" abroad. $^{120}$

Once the local authority approves the application, usually after about thirty days, the foreign investor must apply for final approval with the central government, which takes about ninety days. ${ }^{121}$ This stage in the approval process requires detailed documentation. ${ }^{122}$ The FIE is required to submit the following: (1) a feasibility study; (2) articles of association of the enterprise; (3) a list of legal representatives for the board of directors; (4) evidence of the foreign investor's legal certification and credit standing; (5) a written response of the local government in the locality of the proposed enterprise; (6) a detailed list of goods and materials needed to be imported; and (7) other documents that might be necessary. ${ }^{123}$ All the documents must be written in or translated into Mandarin Chinese. ${ }^{124}$ Once the application has been approved by the central

investor's [joint venture] to reduce the risk of overlooking critical steps in business development." Id.

117. See, e.g., ChIna ECon. Review, China: Foreign InVestment-Confidence RETURNS (May 16, 2002). In 2001, "15,640 new WFOEs were set up," with a total of "US $\$ 42.98$ [billion]" invested. Id. On the other hand, only " 8,895 joint ventures were set up," with a total of "US \$17.5[billion]" invested. Id. See also FDI Laws and Policies, supra note 89, at 40. "WFOEs are now the wave of the future for FDI in China." Id.

118. See FDI Laws and Policies, supra note 89, at 43.

119. See generally Regulations for the Implementation of the law of the People's Republic of China on Joint Ventures using Chinese and Foreign Investment art. 13 (Sept. 20, 1983), http://www.novexcn.com/jv_use_chin_for_invest.html [hereinafter Implementing Rules]; see also WFOE Law art. 23. The Implementing Rules were established according to Article 23 of the WFOE Law, which states, "The department under the State Council which is in charge of foreign economic relations and trade shall, in accordance with this Law, formulate rules for its implementation, which shall go into effect after being submitted to and approved by the State Council." Id.

120. FDI Laws and Policies, supra note 89, at 44.

121. Id. at 43.

122. Id.

123. Implementing Rules ch. II.

124. Id. art. 9. "[T] $]$ he documents shall be written in Chinese." Id. 
authority, the foreign investor must file, within thirty days, a written request to register its enterprise and receive a business license. ${ }^{125}$

As mentioned, local governments may sometimes enact rules to suit their local interests which contradict the central government. ${ }^{126}$ At times, these conflicts of law can work to the advantage of the foreign investor going through the establishment procedures for an FIE. ${ }^{127}$ For example, when establishing its enterprise in China, Carrefour, a French hypermarket, decided not to go through with the lengthy and difficult central government phase of the approval process. ${ }^{128}$ Instead, Carrefour negotiated only with the local governments. ${ }^{129}$ It hoped that once the enterprise was established and operating, the central government would not shut it down. ${ }^{130}$ The gamble paid off. ${ }^{131}$

By comparison, the approval and application process for the equity joint ventures and cooperative joint ventures at the local and central level are not as extensive; the Chinese partner, rather than the foreign investor, is responsible for submitting and obtaining the proposals and approvals. ${ }^{132}$ However, the approval process by the Chinese authorities can still be as long as several months. ${ }^{133}$ Importantly, all FIEs may be denied if the enterprise is not conducive to the "development of China's national economy,"134 or the project is considered to harm "the social and public interests of China."

125. Id. art. 11.

126. See Chen, supra note 15 , at 7 . "[I]n many areas of commercial activities, business depends on local rules to implement and supplement national laws and ... fill in the gaps." Id. "And in most cases, local authorities are the ones with whom the foreign investor must deal when doing business in China." Id. at 8.

127. Bulls in a China Shop, THE ECONOMIST, Mar. 18, 2004, available at http://www.economist.com/displaystory.cfm?story_id=2495194.

128. Id.

129. Id.

130. Id.

131. Id. "For those who have to battle against local, often unfairly subsidized competition, success usually requires a dash of unorthodoxy." Id.; see also Chen, supra note 15, at 8 . Foreign investors "should not see the local rules ... as only of secondary importance." Id.

132. See Randt, supra note 91, \& 2.03[2].

133. See FDI Laws and Policies, supra note 89, at 53.

134. See Implementing Rules art. 5. The FIE will not be approved if the project is a "detriment to China's sovereignty," violates Chinese law, or is not in conformity with the "requirements of the development of China's national economy." Id.

135. WFOE Law art. 4. "Enterprises with foreign capital must abide by Chinese laws and regulations and must not engage in any activities detrimental to China's public interest." Id.; see also Jiang XiaOJUAN, FDI In ChINA: Contributions to Growth, RESTructuring and COMPETITIVENESS 1, 2-5 (2004). There have been some major controversies regarding the use of FDI in China. Namely, that the rise of FDI in China will lead to "[m]onopolizing the [m]arket," "[t]echnology [d]ependency," "massive drain of Chinese interests," a restriction of state power, and, due to the possible political stance of the FIEs, a negative impact China's "state security." Id. 


\section{B. The Foreign Enterprise in China}

A foreign enterprise, as opposed to a FIE, is a foreign legal entity ${ }^{136}$ and is not considered a Chinese legal person. ${ }^{137}$ Foreign enterprises can take various forms, and differing establishment procedures exist depending on the type of foreign enterprise being established. ${ }^{138}$ This type of FDI vehicle generally takes the form of a company that is registered outside China "in accordance with foreign laws." ${ }^{139}$ For example, a foreign enterprise can be a foreign representative office in China; a branch office; can undertake construction work; can be a presence providing training or supervising; or a foreign entity contracting with a PRC entity ${ }^{140}$ that has no permanent presence in China. ${ }^{141}$ In most cases, a representative office may not engage in business or trade directly, but it may act only as an intermediary. ${ }^{142}$ Branch offices, on the other hand, may conduct business. ${ }^{143}$ However, there are no Implementing Regulations for setting up a branch office in China, which makes it difficult it establish. ${ }^{144}$

136. See Detailed Rules of the Ministry of Foreign Trade and Economic Cooperation (MOFTEC) on the Approval and Control of Resident Representative Offices of Foreign Enterprises (1995), http://www.china.org.cn/english/features/investment/36746.htm [hereinafter Representative Office Law]. Article 8 provides that the foreign enterprise shall be "registered legally in its own country." Id.

137. See The Company Law of the People's Republic of China (1993), http://www.macrochina.com.cn/english/laws/investment/20010413000141.shtml (Apr. 16, 2001) [hereinafter Company Law]. Article 203 states, "[a] foreign company is a foreign legal person, so its branch established within the territory of the People's Republic of China shall not have the status of a Chinese legal person in China." Id.

138. See Representative Office Law ch. II; Company Law ch. IX.

139. Company Law art. 199. This article defines and explains the foreign company: A foreign company may, in accordance with this Law, establish a branch within the territory of the Peoples Republic of China to engage in production and business activities. A foreign company mentioned in this Law means a company registered and incorporated outside the territory of the Peoples Republic of China in accordance with foreign laws.

Id.

140. See Representative Office Law art. 2. "The detailed rules are applied to the resident representative offices which are established by foreign traders, manufacturers, freight agents, contractors, consulting companies, advertising companies, investment firms, leasing companies and other economic and trade organizations (hereinafter referred to as foreign enterprises) within the People's Republic of China." Id.

141. See Sabine Stricker-Kellerer, Taxation of Foreign Companies in China, in 1 DoING BUSINESS IN CHINA III, § 3.1.02[1][b] (2001). "Permanent presence means a fixed place of business through which the business of an enterprise is wholly or partly carried out." Id.

142. Representative Office Law art. 4. "The resident representative offices of the foreign enterprises may engage in non-direct business activities and may, on behalf of their enterprises, conduct business liaison activities, product introductions, market studies and technical exchanges, which are within their business scopes." Id.

143. Company Law art 199. The branch office may "engage in production and business activities." Id.

144. See JONES DAY, supra note 87, 4.4. "[T] he lack of implementing regulations (except 


\section{Tax Advantages for the Foreign Investor in China}

For both the FIE and the foreign enterprise, favorable tax incentives for foreign investors in China exist. ${ }^{145}$ The Foreign Enterprise Income Tax Law of China stipulates that foreign investors who reinvest the profits earned from their FIE or foreign enterprise may receive a refund of up to forty percent of the income paid by the enterprise. ${ }^{146} \mathrm{~A}$ full refund is possible if the reinvestment is created by setting up or expanding an enterprise that is export-oriented or technologically advanced. ${ }^{147}$ The average income tax rate for Chinese enterprises is about thirty-three percent, ${ }^{148}$ while the average FIE or foreign company enjoys a rate of about seventeen percent. ${ }^{149}$ FIEs may be taxed on their "worldwide income," while foreign enterprises with a location in China may only be taxed on the income attributed to that establishment. ${ }^{150}$ Because it is difficult to determine the income generated within China from that generated outside, these items should be noted carefully in the initial contract to avoid problems. $^{151}$

If the enterprise is set up in an "Economic and technical Development Zone," 152 those areas where technological development is needed the most, ${ }^{153}$ the tax rate for the enterprise can be as low as fifteen percent ${ }^{154}$ or waived altogether. ${ }^{155}$ These tax breaks afforded to the foreign investor will not last, however. ${ }^{156}$ In order to become WTO compliant, China intends to establish a

for certain specified industries such as banking) usually makes the establishment of branches by foreign companies extremely difficult, if not impossible." Id.

145. See generally Stricker-Kellerer, supra note 141.

146. Laurence Lipsher, Updates on Tax, 6 CHINA L. UPDATE 1 (2003).

147. See Stricker-Kellerer, supra note 141, § 3.1.02[4][b].

148. Id. § 3.1 .01

149. See Lipsher, supra note 146, at 2.

150. See Stricker-Kellerer, supra note 141, § 3.1.02[2][a].

151. Id. The author gives the example of "engineering services," where it is often difficult to "distinguish income derived from this type of service from income such as royalties from technology licensing or income from technical assistance." Id.

152. See id. \$3.1.02[4](c).

153. See, e.g., Markus Taube, Main Issues on Foreign Investment in China's Regional Development: Prospects and Policy Challenges, in OECD, FOREIGN DIRECT INVESTMENT IN CHINA 17, 35 (2002). The author describes an area in need of economic help as one that is "disadvantaged" regarding its ability to attract FDI in China. For instance, these regions may be "far removed from the world market [and] . . . handicapped by a reform and open door policy that has discriminated against them . ... [i]n addition there was a substantial brain drain ... observed during recent years." Id.

154. See Stricker-Kellerer, supra note $141, \S 3.1 .02$ (4) (c) (1); see also Income Tax Law of the People's Republic of China for Enterprises with Foreign Investment and Foreign Enterprises (1991), http://www.china.org.cn/english/14960.htm. Article 7 of this law states, "enterprises with foreign investment of a production nature in economic, and technological development zones shall be levied at the reduced rate of fifteen percent." Id.

155. See FDI Laws and Policies, supra note 89, at 55.

156. See Lipsher, supra note 146 , at 2 . "China will raise the tax rate for most foreign firms with implementation of a unified enterprise income tax as soon as possible ...." Id.; see also FDI Laws and Policies, supra note 89, at 55. "[G]overnment ministry officials are 
uniform tax provision that will do away with any preferential treatment. ${ }^{157}$ Therefore, FIEs intending to invest in a "special economic zone" for the benefit of the tax break need to be aware of the impending change in the law. ${ }^{158}$

\section{DISPUTE RESOLUTION FOR THE FOREIGN INVESTOR}

The increase of foreign investment in China has also increased the number of disputes, ${ }^{159}$ and the foreign investor should be aware of the various methods of dispute resolution available in China. First, the cultural differences in dispute resolution between the Chinese and many Western societies is a very important consideration. ${ }^{160}$ Even after the establishment of the PRC, traditional Chinese notions towards resolving conflicts still influence society. ${ }^{161}$ Unlike the Western model of dispute resolution, litigation in China is usually avoided at all costs. ${ }^{162}$ Instead, the Confucian ideal of maintaining "harmony" usually leads the parties to seek mediation or arbitration rather than resorting to a lawsuit. ${ }^{163}$ Instead of insisting on his own interests, the Confucian "should willingly accept any infringement" on his rights in order to achieve harmony in the society. ${ }^{164}$ For example, the Chinese businessman would take it as an indication that the parties did not trust each other if they were to bring in lawyers during the process of FDI negotiations. ${ }^{165}$ Other traditional philosophies in China, such as Buddhism and Taoism, also follow the

contemplating phasing out the preferential tax rate in order to harmonize domestic tax rates." ld.

157. See Peerenboom \& Xu, supra note $90, \S 3.02(3)$. The "preferential tax treatment may be eliminated as . . . tax authorities move to level the playing field for domestic and foreign companies, in part to meet the standards for ... WTO ...." Id.

158. See FDI Laws and Policies, supra note 89, at 55. Removing the tax advantages for foreign companies "will work to the disadvantage of foreign companies already invested in SEZs and create a less attractive opportunity for potential future foreign investors." Id.

159. See Mo Zhang, International Civil Litigation in China: A Practical Analysis of the Chinese Judicial System, 25 B.C. INT'L \& COMP. L. REV. 59, 62 (2002). China's growing economy and the increase in "transnational business transactions" has "increased" the number of disputes. Id.

160. See generally Bobby K. Y. Wong, Chinese Law: Traditional Chinese Philosophy and Dispute Resolution, 30 H.K. L.J. 304 (2000) (highlighting the philosophical and traditional origins of dispute resolution in China as well as comparing Western and Chinese methods of resolving disputes).

161. See id. at 305.

162. See Urs Martin Lauchli, Cross-Cultural Negotiations, with a Special Focus on ADR with the Chinese, 26 WM. MITCHELL L. REv. 1045, 1062 (2000). The author quotes the Chinese proverb that illustrates the Chinese dislike of litigation, "It is better to die of starvation than to become a thief; it is better to be vexed to death than to bring a lawsuit." Id.

163. See Wong, supra note 160 , at 310 .

164. Id.

165. See FDI Regulations \& Dispute Resolution Mechanisms, supra note 84, at 130. "In fact, lawyers would normally only be brought in after the FDI contract has already been negotiated." Id. 
preservation-of-harmony model and seek to resolve conflicts via mediation and conciliation rather than litigation. ${ }^{166}$

These traditional ideas have carried through to the various methods of resolving business disputes. ${ }^{167}$ Mediation, arbitration, and litigation are all methods of dispute resolution with Chinese entities, but those that involve "amiable consultation" are the most favored. ${ }^{168}$ Arbitration is the preferred ${ }^{169}$ and most popular method in China for both the foreign investor, who is often uncertain about litigating in Chinese courts, and the Chinese counterpart, usually the party more inclined to the process of "friendly consultation" when faced with a business dispute. ${ }^{170}$ As a foreign investor, resolving business disputes in China presents several issues and potential pitfalls, and it is important that some means for resolving disputes be mutually agreed upon before commencing the business relationship. ${ }^{171}$ The advantages and disadvantages of choosing either to arbitrate a dispute before an arbitration commission or to litigate in Chinese courts revolve around issues of neutrality, the expertise involved in making that determination, and award enforcement. ${ }^{172}$

\section{A. Consultation or Mediation}

Consultation, basically an informal discussion between the parties to try to achieve a settlement, is a favored way of solving disputes and is well-suited

166. See generally Wong, supra note 160 , at 308-16 (illustrating the various traditions and philosophies in Chinese history and their related dispute resolution mechanisms).

167. See Patricia Pattison \& Daniel Herron, The Mountains Are High and the Emperor is Far Away: Sanctity of Contract Law in China, 40 AM. Bus. L.J. 459, 460 (2003). Cultural differences between Western and Chinese contracting parties is an important consideration. For example, a "final contract" from a Western perspective indicates a culmination of the negotiating process while from a Chinese perspective, the final contract "signifies that a relationship exists and terms-negotiation may now continue." Id. In other words, the "real" negotiations can now begin. $I d$.

168. See id.

169. See Freshfields Bruckhaus Deringer, The Resolution of China Disputes THROUGH ARBITRATION,

http://www.freshfields.com/practice/disputeresolution/publications/pdfs/8287.pdf [hereinafter FRESHFIELDS].

170. See id. at 2. "Chinese businessmen," when faced with a contractual problem, expect either that the "strict terms of the contract should not be enforced" or that "the contract should be renegotiated according to the changing circumstances." Id. The concept of "equity" rather than "strict legal rights" guides the dispute resolution process more often in China. Id.

171. See Freshfields BRUCKHAUS DERINGer, Dispute Resolution In INTERNATIONAL TRANSACTIONS, at www.freshfields.com/practice/disputeresolution/publications/pdfs/12552.pdf (2005) [hereinafter FRESHFIELDS II]. "[T] he best opportunity to manage the resolution of any future disputes is when documentation is being prepared." $I d$. at 1 .

172. See generally FRESHFIELDS, supra note 169 (explaining the various factors that influence a foreign party's decision as to which dispute resolution mechanism to choose). 
to Chinese culture. ${ }^{173}$ Usually, "people's mediation committees, administrative bodies, arbitral tribunals or courts" conduct mediations. ${ }^{174}$ Indeed, negotiation and mediation are often compulsory phases in the dispute resolution process before beginning any arbitration or litigation in China. ${ }^{175}$ However, because the arbitrators may meet ex parte with any of the parties during the mediation process in order to secure a settlement, the FIE or the foreign enterprise may have concerns about bias or "corruption" during the process. ${ }^{176}$ Also, because of the "non-binding nature" of this form of dispute resolution, it works best when both parties recognize that it is in their best interests to participate in the proceedings and that it is not necessary to come to a firm agreement regarding its use beforehand. ${ }^{177}$ Nevertheless, if this casual form of dispute resolution fails to rectify the problems, the FIE and the foreign enterprise may decide to move on to arbitration. ${ }^{178}$

\section{B. Arbitration}

The Arbitration Law of the People's Republic of China (Arbitration Law) was adopted on August 31, 1994, to promote the fair resolution of disputes and specifies the procedures for arbitration in China. ${ }^{179}$ In addition to the Arbitration Law, the Law of Civil Procedure of the People's Republic of China (CPL) contains regulations that govern arbitrations in China. ${ }^{180}$ Moreover, each arbitration commission may have its own rules. ${ }^{181}$ However, the Arbitration Law takes precedence over other laws regarding arbitration in China. ${ }^{182}$

173. See FDI Regulations \& Dispute Resolution Mechanisms, supra note 84, at 131. See also Lauchli, supra note 159, at 1046 (explaining that in Chinese society, mediation is a "natural extension of the Confucian ethics").

174. See Lauchli, supra note 162, at 1047.

175. See FRESHFIELDS, supra note 169, at 2.

176. Randall Peerenboom, The Evolving Regulatory Framework for Enforcement of Arbitral Awards in the People's Republic of China, 1 AsIAN-PAC. L. \& POL'Y J. 12, 23 (2000) [hereinafter Regulatory Framework]. The problem of "biased" arbitrators usually occurs when the parties combine "mediation with arbitration," leading to the arbitrators becoming "corrupted as a result of the mediation." Id.

177. See FRESHFIELDS, supra note 169, at 2. "Because the success of the process depends upon both parties acknowledging throughout that it is in their best interests to participate, a prior commitment at the time the contract is signed may be ineffectual if either party has turned against it by the time the dispute has arisen." Id.

178. See FDI Regulations \& Dispute Resolution Mechanisms, supra note 84, at 136.

179. Arbitration Law of the People's Republic of China (1994), http://english.sohu.com/2004/07/04/78/article220847885.shtml (last updated July 4, 2004) [hereinafter Arbitration Law]. "This law is formulated with a view to ensuring fair and timely arbitration of disputes over economic matters, safeguarding the legitimate rights and interests of the litigants and guaranteeing the sound development of the socialist market economy." Id. art. 1.

180. See The Law of Civil Procedure of the People's Republic of China (Apr. 9, 1991), http://en.chinacourt.org/public/detail.php?id=2694 (last updated June 3, 2003) [hereinafter CPL]. Chapter XXVIII discusses arbitration.

181. Hunton \& Williams LLP, ChINA: A PERSPECTIVE on INTERNATIONAL ARbTtRation, 
In order for the foreign investor to bring a dispute to arbitration, there must be an "arbitration agreement," or arbitration clause, written into the parties' contract. ${ }^{183}$ The arbitration agreement must contain all of the following elements to be valid. ${ }^{184}$ First, "an expressed intent to request arbitration" must be noted in the arbitration clause. ${ }^{185}$ Second, the "items for arbitration" 186 must be mentioned. Finally, "the chosen arbitration commission" 187 must be indicated specifically. ${ }^{188}$ As with choosing the arbitration commission, the party who negotiates the most favorable arbitration clause usually depends on the relative bargaining strength of the parties. ${ }^{189}$ The arbitration clause is independent of the contract and any "changes to, rescission, termination or invalidity of the contract" will not affect the arbitration clause's validity. ${ }^{190}$ However, there are certain circumstances that may invalidate an arbitration clause, such as coercion, ${ }^{191}$ of which the foreign investor must be aware. Both the FIE and the foreign enterprise are affected in certain strategic aspects of arbitration, such as the arbitration commission chosen, the composition of the arbitration panel, and award enforcement options.

at

http://www.hunton.com/files/tbl_s47Details/FileUpload265/144/Int_Arb_Newsletter_winter200 3-04.pdf (2004); see also, e.g., China International Economic and Trade Arbitration Commission, Arbitration Rules (2004), http://www.cietac.org.cn/english/rules/rules.htm [hereinafter CIETAC Rules]. These are the rules to the CIETAC's arbitration.

182. Arbitration Law art. 78. "In the event of conflict between the provisions on arbitration formulated before the coming into effect of this Law and the provisions of this Law, the provisions of this Law shall prevail." Id.

183. Id. art. 5. Article 5 states that when the parties try to settle their disputes through arbitration and the arbitration clause is absent from the contract, the arbitrating body "shall not accept" any application for arbitration. Id.

184. Id. art. 16.

185. Id.

186. Id.

187. Id. For examples of suggested arbitration agreements, see FRESHFIELDS, supra note 169 , at 24 and 46.

188. See Li Zhang, The Enforcement of CIETAC Arbitration Awards, CHINA PRACTICE, at http://www.hk-lawyer.com/2002-2/Feb02-china.htm (n.d.) (last visited Mar. 30, 2006) (mentioning that even specifying "CIETAC Beijing" or CIETAC Shanghai" rather than just "CIETAC" will prevent the clause being considered "imprecise" by the courts).

189. See FRESHFIELDS, supra note 169, at 34 (finding that foreigners will "naturally prefer to maximize the prospects of neutrality by opting for arbitration outside China").

190. Arbitration Law art. 19. However, this provision does not address what happens to the arbitration clause if the contract never comes into effect.

191. Arbitration Law art. 17. The circumstances for invalidating an arbitration clause are as follows:

(1) the items for arbitration agreed upon are beyond the scope of arbitration as prescribed by law; (2) a party to the arbitration agreement is a person having no capacity or with limited capacity for civil conduct; or (3) the arbitration agreement is imposed by one party on the other party by means of coercion.

Id. 


\section{Arbitration Commission}

All arbitrations are conducted through arbitration commissions, either domestic or international, depending on the legal status of the parties to the dispute. ${ }^{192}$ Currently, there are over 140 local arbitration commissions established in China that hear solely domestic cases. ${ }^{193}$ The most active local arbitration commission is the Beijing Arbitration Commission. ${ }^{194}$ The most popular international arbitration commission in China is the China International Economic and Trade Arbitration Commission (CIETAC). ${ }^{195}$ CIETAC was established in $1956^{196}$ and handled about 850 cases in 2004 alone. ${ }^{197}$

In the past, FIEs were not considered sufficiently international by Chinese courts for purposes of availing themselves of an international arbitration commission. ${ }^{198}$ Therefore, only domestic arbitration was open to them. ${ }^{199}$ Chinese legal persons, such as FIEs, may arbitrate with other Chinese entities or other FIEs as domestic disputes, rather than as international disputes. ${ }^{200}$ Even WFOEs are considered domestic in China despite being wholly foreignowned. ${ }^{201}$ In contrast, the foreign enterprise is considered a foreign body and therefore falls under the international classification. ${ }^{202}$

192. See generally Arbitration Law arts. 10-12 (defining the arbitration commission, the composition of the arbitration commission and how they are established ).

193. See HuNTON \& WILLIAMS LLP, supra note 181.

194. Id. However, now the local arbitration commissions may hear "all kinds of disputes as agreed by the parties." Id. For more information on the Beijing Arbitration Commission, see http://www.bjac.org.cn/en/index.asp.

195. See FRESHFIELDS, supra note 169, at 11 (noting that parties to an international dispute in China will "almost inevitably do so according to the rules of CIETAC").

196. See China International and Economic Trade Arbitration Commission, Introduction, at http://www.cietac.org/.

197. Darren FitzGerald, MinterEllison, CIETAC'S new rules: Do the reforms go FAR ENOUGH? (Aug. 11, 2005), at http://www.minterellison.com/public/connect//nternet/Home/Legal+Insights/Articles/At+CIETACs+new+rules+-+do+the+reforms+go+fartenough.

198. See $\mathrm{Li}$, supra note 188 .

199. See id. In the 1992 case of China International Engineering Consultancy Corp. v. Beijing Lido Hotel Co., an intermediate People's Court held that China International Engineering Consultancy Corp., as an FIE party and thus a domestic entity, did not render the case sufficiently foreign-related. Id. Therefore, CIETAC did not have proper jurisdiction over the case. Id. As a result, the arbitration agreement naming CIETAC as the arbitration commission was invalid and the award against Beijing Lido was not enforced. It should be mentioned, however, that CIETAC has since amended its rules to include FIEs as falling under its jurisdiction. Id.

200. LAETITIA TJOA, COUDERT BROTHERs LLP, ARBITRATION IN CIETAC - AN UPDATE, at http://www.coudert.com/publications/?action=displayarticle\&id=248 (Oct. 15, 2003).

201. WFOE Law art. 8. "An enterprise with foreign capital which meets the conditions for being considered a legal person under Chinese law shall acquire the status of a Chinese legal person, in accordance with the law." Id.

202. See TrOA, supra note 200. "According to PRC law," if parties are "foreign or domiciled in a foreign country," then the parties are " 'foreign-related.' "Id.; see also Bonnie Hobbs, CIETAC Arbitration Rules and Procedure: Recent Developments and Practical 
In 1998, CIETAC amended its rules to include "international or foreignrelated" and "domestic" disputes within its jurisdiction. ${ }^{203}$ These amendments to CIETAC were seen as beneficial to the FIE because it could now choose to arbitrate in an international arbitration commission and have access to nonChinese arbitrators. ${ }^{204}$ In addition to CIETAC, other popular international arbitration commissions include the Arbitration Institute of Stockholm Chamber of Commerce, ${ }^{205}$ the American Arbitration Association, ${ }^{206}$ and the International Chamber of Commerce. ${ }^{207}$ There are certain perceived advantages to arbitrating in an international arbitration commission rather than in a domestic arbitration commission in China that relate to issues of neutrality and arbitration expertise. ${ }^{208}$ However, even if the foreign enterprise included an arbitration clause stipulating an arbitration commission outside China, it is still possible that the Chinese government may not approve of such a contract. ${ }^{209}$

Guidelines (Apr. 1999), available at

http://www.omm.com/webcode/webdata/content/publications/CIETAC.PDF (last visited Mar. 30, 2006). Article 304 of the Opinion of the Supreme People's Court on Certain Questions Concerning the Application of the Civil Procedure Law states that a case involving a "foreign element" is either: "i. A party to the dispute is a foreigner or a foreign enterprise or organization; ii. Either the establishment or variation and termination of a legal relationship is made outside the PRC; iii. The subject matter in dispute is located outside the PRC." Id.

203. CIETAC Rules art. 3.

204. See Hobbs, supra note 202. "[W]hile the 1998 Amendments seem to broaden access to CIETAC by FIEs," practically, the results are not so attractive. Id.

205. See FRESHFIELDS, supra note 169, at 39. For "historical reasons," this institute is "most favored by Chinese parties" as a neutral venue. $I d$.

206. See generally id. The American Arbitration Association is based in New York. For more information, see http://www.adr.org/index2.1.jsp. See also Covington \& BURLING, A PRIMER ON INTERNATIONAL ARBITRATION 6 (May 1998), available at http://www.cov.com/publications/download/oid6181/PRIMER.PDF. Non-American parties to a dispute may not consider the American Arbitration Association as neutral if one of the parties is American. Id.

207. See generally FRESHFIELDS, supra note 169. The International Chamber of Commerce arbitral procedures are subject to "scrutiny," which "enhances enforceability and ensure[s] against cases of procedural irregularities." Id. at 40. The International Chamber of Commerce is based in Paris. For more information, see http://www.iccwbo.org (last visited Mar. 30, 2006).

208. See FRESHFIELDS, supra note 169, at 8 (noting that with domestic arbitration commissions "old problems of lack of competence and political interference have not entirely disappeared" and that the rules for domestic arbitration "are less sophisticated" than those designed for international arbitration).

209. Charles Kenworthy Harer, Arbitration Fails to Reduce Foreign Investors' Risk in China, 8 PAC. RIM L. \& PoL'Y J. 393, 402 (1999). "In practice, foreigners must agree to arbitration in a Chinese tribunal, because the Chinese government need not approve contracts with arbitration agreements that provide for tribunals outside of China, and the Chinese courts may void those agreements." Id. But see FRESHFIEI DS BRUCKAUS DERINGER, ASIA ARBITATION 3 (May 2004) (noting that the new draft provisions on foreign arbitration issued by the SPC on Dec. 31, 2003, clearly mention "Chinese law presently permits only foreign-related contracts to provide for arbitration by arbitral institutions outside China"), available at http://www.freshfields.com/places/asia/publications/pdfs/8281.pdf; see also CIETAC Guide: How to Conduct Arbitration in CIETAC, at http://www.cietac.org.cn/english/guide/guide.htm (2004). Section IV, Hearing of Cases, mentions that "[w]ith the approval of the SecretaryGeneral of the Arbitration Commission, the cases can be heard in other places in or outside 


\section{Arbitration Panel selection}

The Arbitration Commission shall appoint "fair minded and respectable persons" to be arbitrators ${ }^{210}$ in addition to the other qualifications necessary for acting as an arbitrator. ${ }^{211}$ The disputes are decided either by a tribunal or a single arbitrator chosen by the parties from a list of arbitrators. ${ }^{212}$ Each party selects an official of the arbitration commission to choose one arbitrator from the list, and the third arbitrator is chosen by agreement between the parties. ${ }^{213}$ If no agreement can be reached, the third arbitrator is chosen by the arbitration commission director. ${ }^{214}$ According to CIETAC arbitration rules, the arbitrating panel may be chosen from a list of arbitrators, foreign and domestic, ${ }^{215}$ and the selected arbitrators do not necessarily have to be from the location where the dispute took place. ${ }^{216}$ Revisions to the CIETAC rules, effective May 1, 2005, allow the parties, by agreement, to choose arbitrators from outside of

China." Id. However, CIETAC does not mention what happens if the Secretary-General does not approve of an outside location for the arbitration.

210. Arbitration Law art. 13.

211. Id. Arbitrators in China must meet at least one of the following conditions: 1. they have been engaged in arbitration work for at least eight years; 2 . they have worked as a lawyer for at least eight years; 3 . they have been a judge for at least eight years; 4. they are engaged in legal research or legal teaching and in senior positions; and 5. they have legal knowledge and are engaged in professional work relating to economics and trade, and in senior positions or of the equivalent professional level. The arbitration commission shall establish a list of arbitrators Id. according to different professionals.

212. See id. art. 30. "An arbitration tribunal may comprise three arbitrators or one arbitrator. If an arbitration tribunal comprises three arbitrators, a presiding arbitrator shall be appointed." Id.

213. See id. art. 31.

If the parties agree to form an arbitration tribunal comprising three arbitrators, each party shall select or authorize the chairmen of the arbitration commission to appoint one arbitrator. . . If the parties agree to have one arbitrator to form an arbitration tribunal, the arbitrator shall be selected jointly by the parties or be nominated by the chairman of the arbitration commission in accordance with a Id. joint mandate given by the parties.

214. See id. art. 31. "The third arbitrator shall be selected jointly by the parties or be nominated by the chairman of the arbitration commission in accordance with a joint mandate given by the parties. The third arbitrator shall be the presiding arbitrator." Id.

215. See CIETAC's list of arbitrators at http://www.cietac.org.cn/english/arbitrators/arbitrators.htm. The list includes both Chinese and foreign arbitrators." Id.

216. See FrESHFIELDS, supra note 169, at 8 . Choosing an arbitration commission from another jurisdiction is aimed at eliminating the "influence of local protectionism." Id. 
"CIETAC's [p]anel of [a]rbitrators." ${ }^{\text {217 }}$ However, these arbitrators must still be "confirmed" by CIETAC. ${ }^{218}$

It must be noted, however, that in the past it was unclear whether or not FIEs, as Chinese legal persons, would have the same access to the international ${ }^{219}$ list of arbitrators as the foreign enterprises or instead would have to choose from the domestic ${ }^{220}$ list. Some authorities said the FIEs would have to choose from the list of Chinese arbitrators reserved for domestic cases, which would greatly reduce the proposed benefits for the FIE to arbitrate with CIETAC. ${ }^{221}$ However, the new 2005 CIETAC rules provide separate arbitrator lists for domestic and international cases. Notably, both lists appear to be available for the foreign enterprise and the FIE. ${ }^{222}$ In any case, for both the FIE and the foreign enterprise, the failure to reach an agreement in choosing the third arbitrator means that the third member of the panel often ends up being chosen $^{223}$ by CIETAC $^{224}$ or whichever arbitration commission is being

217. See CIETAC Rules art 21, II 2. See also FITZGERALD, supra note 197. The author notes that the "loosening of CIETAC's panel system is the most significant of the reforms" because of the "increase" in the "pool of foreigners and experts available to serve on a CITAC tribunal." Id.

218. CIETAC Rules art $21, \mathbb{T} 2$ provides:

Where the parties have agreed to appoint arbitrators from outside of the CIETAC's Panel of Arbitrators, the arbitrators so appointed by the parties or nominated according to the agreement of the parties may act as co-arbitrator, presiding arbitrator or sole arbitrator after the appointment has been confirmed by the Chairman of the CIETAC in accordance with the law.

Id.; see also Julius Melnitzer, Reforms Make Arbitration in China A Safer Bet, INSIDE COUNSEL (July 2005), http://www.insidecounsel.com/issues/insidecounsel/15_164/global_views/1011.html. The article points out that, even with the new 2005 rules, "CIETAC still has the power to reject the parties' choice" and does not "state the criteria for approval" of arbitrators. Id.

219. See CIETAC "Panel of Arbitrators for International (Foreign-related) Disputes," at http://www.cietac.org.cn/english/arbitrators/arbitrators_n1.htm (n.d.) (last visited Apr. 3, 2006).

220. See CIETAC "Panel of Arbitrators for Domestic Disputes," at http://www.cietac.org.cn/english/arbitrators/arbitrators_n2.htm(n.d.) (last visited Apr. 3, 2006).

221. See HunTon \& WiLliams LLP, supra note 181 (noting that the "full panel of CIETAC arbitrators ... will only be available for selection by the parties in a foreign-related arbitration"); see also Hobbs, supra note 202 (noting that the CIETAC arbitrator list "for parties to a dispute involving an FIE does not include foreign arbitrators"). But see FRESHFIELDS, supra note 169, at 13 (stating that in "domestic cases involving an FIE, foreign arbitrators may be selected").

222. See CIETAC "Instructions on the Application of the Panels of Arbitrators," at http://www.cietac.org.cn/english/arbitrators/arbitrators_n8.htm (n.d.) (last visited Apr. 3, 2006). Instruction Two provides, "[t] $]$ he Panel of Arbitrators for Domestic Disputes shall apply to domestic arbitration cases. But if one party or both parties are enterprises with foreign investment, the Panel of Arbitrators for International (Foreign-related) Disputes shall also apply." Id.

223. See Jerome A. Cohen, Time to Fix China's Arbitration, FAR E. ECON. Rev. (Jan/Feb 2005), http://www.feer.com/articles $1 / 2005 / 0501 /$ free/p031.html. While the third arbitrator in a CIETAC arbitration "is most probably going to be Chinese," the Beijing Arbitration Commission requires each party to submit "lists of names of persons" each party "could accept" and the presiding arbitrator is chosen from among these names. Id.; see also FITZGERALD, supra note 197. The author notes that even the new rules do not require the "sole or presiding 
employed. This scheme may create an opportunity for bias. ${ }^{225}$ Therefore, the foreign investor must be aware that even with the 2005 CIETAC amendments, issues of unfairness ${ }^{226}$ and non-neutrality within the arbitration proceeding can still exist. $^{227}$

\section{Award enforcement}

Arbitration award enforcement is governed by the Arbitration Law and the CPL. ${ }^{228}$ The Arbitration Law of China recognizes a type of res judicata ${ }^{229}$ with respect to decisions made by an arbitration commission. ${ }^{230}$ However, a party may still challenge the award rendered by the arbitration commission on certain grounds and ask that the arbitration award be "set aside" or cancelled."

arbitrator" to be of a neutral third country. Id. If the parties fail to expressly name the presiding or sole arbitrator in the arbitration clause, CIETAC will most likely appoint a "Mainland Chinese" arbitrator. Id.

224. See Arbitration Law arts. 30-33; see also CIETAC Rules arts. 20-22.

225. See FRESHFIELDS, supra note 169 , at 17 . In the absence of an agreement for the third panelist, the rules do "not stipulate that if the choice is left in the hands of that institution, the appointee must be neutral" and the "general trend has been for the CIETAC appointee to be Chinese." Id.

226 See Cole Sternberg, Chinese Courts: More of a Gamble than Arbitration?, 4 INT'L Bus. L. REv. 31, 36 (2004). The problem is not that CIETAC itself is biased, only that the system of "internal panelist review" is faulty and the commission does not always conduct "due diligence investigations into the case and potential panelists prior to selection." Id.; see also Cohen, supra note 223. The author criticizes CIETAC's use of "its own personnel as arbitrators, especially the presiding arbitrator" since it "creates an obvious opportunity for the exercise of administrative influence and even control over the arbitration panel and its decision." Id.; see also Melnitzer, supra note 218. The new rules "continue to allow CIETAC to use its own personnel as arbitrators." Id. But cf. Johnson Tan, A Look at CIETAC: Is it Fair and Efficient?, 17 CHINA L. \& PRAC. 24, 25 (Apr. 2003) (noting that there is "no evidence" that a Chinese arbitrator would "favor a fellow national" but an American would not).

227. CIETAC is organized under the China Chamber of International Commerce, which is supervised by the PRC State Council. See CIETAC organization, at http://www.cietac.org.cn/english/organization/organization.htm (2004); see also TIMOTHY Stratford, The Am. Chamber of Commerce-P.R.C., Views of AMERICan Companies REGARDING ARBITRATION IN CHINA (2001), available at www.AmCham-China.org.cn. In response to an American Chamber of Commerce survey, U.S. Embassy officials mention, "[i]t has been reported that certain arbitrators have had outside relationships to parties in the case that have not been disclosed." Id.

228. See generally Arbitration Law; CPL.

229. See Hunton \& WILLIAMS LLP, supra note 181.

230. Arbitraton Law art. 9. A "single ruling system shall be applied in arbitration" in China. Id.

231. See Hunton \& Williams LLP, supra note 181; see also Arbitration Law art. 58. There are specific grounds for applying to cancel an arbitration decision:

The parties may apply to the intermediate people's court at the place where the arbitration commission is located for cancellation of an award if they provide evidence proving that the award involves one of the following circumstances: 1 . there is no arbitration agreement between the parties; 2 . the matters of the award are beyond the extent of the arbitration agreement or not within the jurisdiction of the arbitration commission; 3 . the composition of the arbitration tribunal or the arbitration procedure is in contrary to the legal procedure; 4 . the evidence on 
Accordingly, it is important for the foreign investor to include the arbitration clause in the main contract and any collateral contract to avoid invalidation and forfeiture of any award earned. ${ }^{232}$

Article 63 of the Arbitration Law governs enforcement of arbitral awards for the domestic entity. ${ }^{233}$ It stipulates that under the circumstances of CPL Article $217,{ }^{234}$ the court may not enforce the award against the losing party. ${ }^{235}$ In a domestic dispute, which includes the FIE, if a party fails to abide by the arbitral award, the winning party must apply to the people's court to enforce the award. ${ }^{236}$ However, it is "notoriously difficult" for judges to enforce awards in such circumstances. ${ }^{237}$ Significantly, the court may not only review the procedure carried out by the arbitration commission, but also the substantive legal issues of the case when deciding whether to enforce the award. ${ }^{238}$ The

which the award is based is falsified; 5 . the other party has concealed evidence which is sufficient to affect the impartiality of the award; and 6. the arbitrator(s) has (have) demanded or accepted bribes, committed graft or perverted the law in making the arbitral award. The peoples' court shall rule to cancel the award if the existence of one of the circumstances prescribed in the preceding clause is confirmed by its collegiate bench. The people's court shall rule to cancel the award if it holds that the award is contrary to the social and public interests.

Id.

232. See $\mathrm{Li}$, supra note $\mathbf{1 8 8}$ (having an arbitration clause in the main contract "does not necessarily imply" that all collateral contracts are covered by that agreement).

233. Arbitration Law art. 63. The Arbitration Law has "special provisions" for foreign related awards starting with article 65 of the law. Id. art 65 .

234. CPL art. 217. The following are grounds for refusing to enforce an arbitral award for a domestic entity:

(1) The litigants neither stipulated arbitration provisions in their contract nor reached a written agreement of arbitration afterwards; (2) The matter being adjudicated falls neither within the limits of the agreement of arbitration nor the limits of the arbitration organ's authority; (3) The formation of the arbitration tribunal or the arbitrating procedure violate the legal procedure; (4) The crucial evidence is found to be insufficient; (5) The application of the law is found to be erroneous; (6) The arbitrator is found to have taken bribes, conducted malpractice out of personal considerations, and misused the law in rendering a verdict in the course of arbitration. The people's court shall rule that the verdict is not to be executed should it certify that the execution runs counter to the society's public interests.

Id.

235. Arbitration Law art. 63. "A people's court shall, after examination and verification by its collegiate bench, rule not to enforce an award if the party against whom an application for enforcement is made provides evidence proving that the award involves one of the circumstances prescribed in Clause 2, Article 217 of the Civil procedure Law." Id.

236. Arbitration Law art. 62. "When one litigant fails to abide by the ruling, the other litigant may, in accordance with provisions in the Law of Civil Procedure, request the people's court execute the ruling, and the people's court that accepts the request shall execute the ruling." Id.

237. Regulatory Framework, supra note 176, at 53.

238. See generally Randall Peerenboom, Seek Truth From Facts: An Empirical Study of Enforcement of Arbitral Awards in the PRC, 49 AM. J. CoMP. L. 249, 289 (2001) (comparing domestic and foreign enforcements regulations) [hereinafter Empirical Study of Enforcement]; see also CPL art. 217. The court may refuse to enforce an arbitral award if "[t]he crucial evidence is found to be insufficient" or "[ $t]$ he application of the law is found to be erroneous." 
fact that a Chinese court may review a case on the merits seriously weakens the effect of finality of an arbitral award for the FIE. ${ }^{239}$

On the other hand, for the foreign enterprise, which is considered a dispute involving a foreign element, ${ }^{240}$ challenges to the arbitral award are governed by Article 260 of the CPL. ${ }^{241}$ Article 260 of the CPL, like Article 58 of the Arbitration Law, sets forth the circumstances for invalidating or setting aside an arbitration award for "disputes involving foreigners." 242 Refusal of the courts to enforce a foreign arbitral award is based on procedural errors in the arbitration process, rather than a review of the substantive issues of the dispute. $^{243}$ In addition, as opposed to domestic arbitration, if the foreign investor arbitrates a dispute through CIETAC or another international arbitration commission and loses, the Chinese party may apply to enforce the award in the foreigner's country ${ }^{244}$ whereas "local protectionism and nationalism weigh against foreign applicants seeking enforcement in China."245 This makes it difficult for the losing party to secure its assets. ${ }^{246}$ However, as with domestic and international enforcement applications, a people's court "shall decide not to enforce an arbitration ruling which it deems contrary to social and public interests." ${ }^{247}$ The social and public interests that would cause

Id. The CPL has special provisions for foreigners starting at article 237. Id. art. 237.

239. See Hobbs, supra note 202.

240. See supra note 202.

241. Arbitration Law art. 71. Under "Chapter VII Special provisions on Foreign-Related Arbitration": "A people's court shall, after examination and verification by its collegiate bench, rule not to enforce an award-if the party against whom an application is made provides evidence proving that the arbitration award involves one of the circumstances prescribed in Clause 1 , Article 260 of the Civil Procedure Law." Id.

242. See CPL art. 260. The circumstances for invalidating an arbitration clause are:

(1) Where the contract does not contain an arbitration clause, or where the parties concerned do not conclude a written agreement on arbitration subsequently; (2) Where the object of the application is not informed of the need to designate an arbitrator or initiate arbitration proceedings, or where the object of the application cannot state his opinions due to reasons for which he cannot be held accountable; (3) Where the creation of an arbitration court, or the initiation of arbitration proceedings, does not conform to arbitration rules; (4) Where the matter to be arbitrated falls outside the scope of the arbitration agreement or the jurisdiction of the arbitration agency.

Id.

243. See generally CPL art. 260.

244. See Harer, supra note 209 , at 397 . "If a foreign party loses in an arbitration tribunal to a Chinese party, the Chinese courts will likely enforce the award, and the Chinese party stands an excellent chance of pursuing enforcement of an award in the foreigner's home country." Id.

245. Empirical Study of Enforcement, supra note 238, at 270; see also Harer, supra note 209 , at 397 . The author mentions that if the foreign party is successful in the arbitration, it is "not likely collect absent enforcement through the courts." Id.

246. Empirical Study of Enforcement, supra note 238, at 292; see also Regulatory Framework, supra note 176, at 46. "[L]ocal protectionism means that local governments help companies in which they have economic interest hide assets or dodge debts." Id.

247. CPL art. 260. See also id. art. 217. "The people's court shall rule that the verdict is not to be executed should it certify that the execution runs counter to the society's public 
an award not to be enforced are not defined in the law. ${ }^{248}$ In addition, decisions to enforce or refuse to enforce an award "cannot be appealed."249

The United Nations Convention on the Recognition and Enforcement of Foreign Arbitral Awards (New York Convention) provides that China will recognize arbitral awards made in countries of other signatories. ${ }^{250}$ The New York Convention rules do not allow a substantive review of the case before enforcing an award. ${ }^{251}$ Interestingly, the New York Convention specifies that apart from serious procedural errors in the arbitration process, ${ }^{252}$ the courts "may" refuse to recognize an award if it meets certain criteria. ${ }^{253}$ However, the

interests." Id.; see also Empirical Study of Enforcement, supra note 238, at 289 (pointing out that fears that this clause would be used to invalidate any award in favor of a foreign party were "not entirely groundless").

248. See generally CPL arts. 1-270.

249. Regulatory Framework, supra note 176, at 38.

250. United Nations Convention on the Recognition and Enforcement of Foreign Arbitral Awards (1958), http://www.jus.uio.no//m/un.arbitration.recognition.and.enforcement.convention.new.york. 1958 /doc.html [hereinafter New York Convention]. Article 1 states that

[t]his Convention shall apply to the recognition and enforcement of arbitral awards made in the territory of a State other than the State where the recognition and enforcement of such awards are sought, and arising out of differences between persons, whether physical or legal. It shall also apply to arbitral awards not considered as domestic awards in the State where their recognition and enforcement are sought.

Id. China is a 1987 signatory to the New York Convention. Id.

251. Empirical Study of Enforcement, supra note 238, at 265. The "grounds for refusing to enforce [New York] Convention ... awards are limited to procedural violations." Id.; see also New York Convention art. V. Refusal to recognize an award is based on the following:

(a) The parties to the agreement referred to in article II were, under the law applicable to them, under some incapacity, or the said agreement is not valid under the law to which the parties have subjected it or, failing any indication thereon, under the law of the country where the award was made; or (b) The party against whom the award is invoked was not given proper notice of the appointment of the arbitrator or of the arbitration proceedings or was otherwise unable to present his case; or (c) The award deals with a difference not contemplated by or not falling within the terms of the submission to arbitration, or it contains decisions on matters beyond the scope of the submission to arbitration, provided that, if the decisions on matters submitted to arbitration can be separated from those not so submitted, that part of the award which contains decisions on matters submitted to arbitration may be recognized and enforced; or (d) The composition of the arbitral authority or the arbitral procedure was not in accordance with the agreement of the parties, or, failing such agreement, was not in accordance with the law of the country where the arbitration took place; or (e) The award has not yet become binding, on the parties, or has been set aside or suspended by a competent authority of the country in which, or under the law of which, that award was made.

Id.

252. See Li, supra note 188.

253. See generally id. (comparing the language of the New York Convention regulations with the language of the Arbitration Law in regards to award enforcement); see also New York Convention art. V. "Recognition and enforcement of the award may be refused ... where the recognition and enforcement is sought." Id. 
language in the Arbitration Law instructs that courts "shall" refuse to enforce the award if it meets the specified criteria. ${ }^{254}$ The New York Convention rules seem to allow the courts discretion to excuse minor infractions and to enforce the award anyway, while the Arbitration Law does not allow for such interpretation. $^{255}$

\section{Litigation}

Both the FIE and the foreign enterprise have the "same ability" to bring an action in Chinese court, ${ }^{256}$ although it is not the most favorable dispute resolution method. ${ }^{257}$ However, in the past several decades, the number of civil cases in Chinese courts has increased despite the aversion to conflict. ${ }^{258}$ The adversarial system, judicial precedent, and the jury system are frequently absent in Chinese courts. ${ }^{259}$ Instead, the Chinese judicial system is based on the "inquisitorial model," ${ }^{, 260}$ where the judge takes an active role ${ }^{261}$ in the factfinding process without the use of a jury. ${ }^{262}$

Judges in China also often "fail to meet the minimum educational requirements"263 and are often chosen by the CCP as military veterans. ${ }^{264}$ Although the SPC and people's courts are supposed to "exercise judicial power independently,"265 they are still subject to the NPC and the Standing Committee, and the local people's courts are supervised by the legislatures that "created them." 266 This lack of judicial independence is one of the main concerns of foreign parties litigating in China as well as the "Chinese citizenry."267 Although the Constitution provides for the courts to be able to

254. Arbitration Law arts. 70-71. "A people's court shall ... rule to cancel an award if ... the arbitration award involves one of the circumstances prescribed in Clause 1, Article 260 of the Civil Procedure Law." Id.

255. See Regulatory Framework, supra note 176, at 16. Article V of the New York Convention rules gives the courts "some discretionary power to disregard minor defects" when deciding whether to enforce an award. Id.

256. U.S. Government Export PORTAL, China Business Information Center, at http://www.export.gov/china/exporting_to_china/disputeavoidanceandresolution.pdf (last updated Apr. 2003).

257. FRESHFIELDS II, supra note 171, at 11.

258. See Mo, supra note 159 , at 62 .

259. See Pattison \& Herron, supra note 167, at 505.

260. Zhong Jianhua \& Yu Guanghua, Establishing the Truth on Facts: Has the Chinese Civil Process Achieved This Goal?, 13 J. TRANSNAT'L L. \& POL'Y 393, 400 (2004).

261. Id. at 393.

262. Id. at 394. "Chinese judges not only decide issues of law but also those of fact." Id.

263. See id. at 438; see also Mo, supra note 159, at 94 . "Among the presidents and vicepresidents of the people's courts, only $19.1 \%$ " have a bachelor degree or higher" and "many of them have not graduated from law school." Id.

264. Regulatory Framework, supra note 176, at 9.

265. XIANFA art. 126.

266. Id. art. 128.

267. Mo, supra note 159 , at 92 . 
exercise judicial powers independently, it does not work this way in fact. ${ }^{268}$ For example, the CCP may "exert[] its pervasive influence and control over the judiciary" through a committee ${ }^{269}$ headed by government officials. ${ }^{270}$ While this committee does not directly hear the cases, it may "discuss" and "make decisions about cases" that it identifies as "politically sensitive," and it has the power to remove judges. ${ }^{271}$

Although required to protect the legal rights of the parties they represent, ${ }^{272}$ Chinese "lawyers, law firms and lawyer's associations" are still supervised by the central government. ${ }^{273}$ Therefore, attorneys in China will refrain from vigorously representing their clients in court litigation "because they risk damaging their careers." 274 More troubling for the foreign investor is that neither FIEs nor foreign enterprises have the option of procuring a foreign lawyer to represent them in a suit ${ }^{275}$ because foreign lawyers may not practice Chinese law." 276 Foreign lawyers may, however, offer "legal consulting service," such as recommending Chinese law firms to clients in China. ${ }^{277}$ Further, due to historical reasons, ${ }^{278}$ there is a shortage of lawyers in China, they are poorly trained, ${ }^{279}$ and they lack independence. ${ }^{280}$

268. Id. at 93 .

269. Zhong \& Yu, supra note 260 , at 414 . The committee is called the "Political and Legal Committee" and it is chaired by the "head of the Public Security Bureau." Id. at 415.

270. Id. at 414-15.

271. Id. at 415; see also XIANFA art. 63. "The National People's Congress has the power to recall or remove from office the following persons ... [t]he President of the Supreme People's Court." Id.

272. See Zimmerman, supra note 34 , at 39.

273. Id. at 40. In a 1993 survey of Chinese lawyers, " 94 percent of the 127 interviewed" said the government "interfered" with their "legal work." Id.

274. Id.

275. CPL art. 241. "Where foreigners, stateless persons, foreign enterprises and organizations want to have legal representatives in taking or responding to actions in the people's court, they must entrust their cases to lawyers of the PRC." Id.

276. See Charles Chao Liu, Note and Comment, China's Lawyer System: Dawning Upon The World Through A Tortuous Process, 23 WHITTER L. REV. 1037, 1071 (2002).

277. Id. at 1070.

278. See Zhong \& Yu, supra note 260 , at 438 . During the Cultural Revolution, law schools were closed and the judicial system was "virtually wiped out." Id.; see also Chengyuan Lu, Legal Services in China: Facing the WTO, 20 UCLA PAC. BASIN L.J. 278, 322 (2003). The ratio of Chinese lawyers to the entire population is " $0.8 / 10,000$," whereas in the United States, it is about " $32 / 10,000$." Id.

279. See Pattison \& Herron, supra note 167, at 507. Approximately one fifth of Chinese lawyers have a legal education. In addition, even fewer judges have any "formal university education in law." Id.

280. See Regulatory Framework, supra note 176, at 9. "[A]lthough direct intervention by the CCP . . . is lessening, judges still discuss important political cases or cases involving difficult legal issues with the Political-Legal Committee. More generally, the CCP exercises control over the court by setting general policies ... within which the courts must operate." Id:; see also Zhong \& Yu, supra note 260 , at 414 . The "Chinese judiciary . . is vulnerable to outside interference, particularly from the Party ... [T] [Te Party is China's major decision maker." Id. 
In addition, problems with enforcement of legal judgments continue to plague China. ${ }^{281}$ When the losing party to a judgment refuses to comply with a judgment handed down by a people's court, the procedure begins with filing a petition in a people's court. ${ }^{282}$ An "enforcement officer" handles the enforcement of the judgment, and then notifies the nonpayer and directs it to comply with the judgment. ${ }^{283}$ If the debtor still does not obey the judgment, the enforcement officer may "explore other enforcement devices to compel the debtor to satisfy the judgment.",284 However, it is "difficult" to enforce legal judgments in China. ${ }^{285}$ Much of the resistance to complying with legal judgments is due to local protectionism. ${ }^{286}$ Also, because disputes involving an FIE are considered domestic, ${ }^{287}$ enforcement is usually left to trial courts. ${ }^{288}$ When "different counties or prefectures" are involved, local government desire to "protect local industries or business" makes it hard for the trial court to enforce judgments. ${ }^{289}$

A full discussion of the intricacies of the advantages of arbitration over litigation in China is beyond the scope of this Note. Overall, among the advantages of arbitration over litigation in court is that arbitration is usually confidential $^{290}$ and more impartial. ${ }^{291}$ Arbitration tends to be "less adversarial" than litigation, so the future of the business relationship can be protected. ${ }^{292}$ Also, the expertise of the arbitrators is an attractive characteristic of arbitration

281. See Winning is Only Half the Battle, THE ECONOMIST, Mar. 23, 2005, available at http://www.economist.com/research/articlesBySubject/displayStory.cfm?story_ID=3797564\&su bject $=\mathrm{HK}$ [hereinafter Winning].

282. See Mo, supra note 159 , at 86.

283. Id. at 87.

284. Id.

285. Id. at 90; see also FRESHFIELDS II, supra note 171, at 10 (noting that "particularly in transactions involving emerging markets, arbitration may be the only option to ensure that you can obtain an enforceable result").

286. Mo, supra note 159 , at 91 . "Local protectionism is the main obstacle to enforcement." Id.

287. See supra note 200.

288. Mo, supra note 159, at 91.

289. See id.

290. See FRESHFIELDS, supra note 169, at 21 (noting that international arbitration hearings "take place behind closed doors"). Cf. Stemberg, supra note 226, at 44 (describing that what remains private is the panel's decision making process and not the final award itself ).

291. FRESHFIELDS, supra note 169, at 21 ; see also Arbitration Law art. 14. This provisions states that the Arbitration Commissions are "independent from administrative organs" and are not "subordinate" to any administrative organs. Id.; see also STRATFORD, supra note 227. Sixty percent of the American companies who responded to the American Chamber of Commerce survey on arbitration in China said that arbitration in "major Chinese arbitration centers" tended to be "more fair" than litigation in Chinese courts. Id.; see also GARZ, supra note 55. "[L]ocal governments and local CCP committees control the personnel and financial arrangements of the local courts. Appointment and dismissal of judges and provision of salaries are determined by local government and CCP committees." Id.

292. Franki Cheung, CIETAC Opens Doors to Financial Arbitration, 17 CHINA L. \& PRAC. 22 (2003). 
compared to litigation in Chinese courts. ${ }^{293}$ An indication of this expertise is illustrated by the CIETAC requirement that each arbitrator display "professional knowledge of law, economy and trade, science and technology or maritime affairs, and ... working experience."294

It is important to know that decisions made by Chinese courts in litigation are subject to appeal, ${ }^{295}$ while arbitral decisions are final. ${ }^{296}$ The foreign investor also has the perception that there is more "control" over the proceedings in terms of drafting the arbitration clause, choosing the arbitration commission, and selecting the arbitrators. ${ }^{297}$ Furthermore, The Economist estimates that "[n]ationwide," approximately " $60 \%$ of court rulings are enforced"; 298 and this number can "drop to $10 \%$ " when court officers from other jurisdictions are trusted to enforce the rulings. ${ }^{299}$ It is no wonder that some authorities advise that litigation in Chinese courts is "not a suitable venue" for foreign investors resolving disputes with a Chinese entity"[a]rbitration is preferred.",300

\section{FUTURE CONSIDERATIONS ${ }^{301}$}

China has shown a great willingness to reform its "weak and developing legal system" to attract foreign investment and create a more favorable and predictable climate for investors by amending its Constitution. ${ }^{302}$ In 1999, China added a phrase to its Constitution: "The People's Republic of China practices ruling the country in accordance with the law and building a socialist country of law." 303 While it is true that most Western foreign investors may still not be clear about the definition of a "socialist country of law," this

293. Id. at 22.

294. See CIETAC's "Conditions for the Appointment of Arbitrators" Foreign arbitrators, $\mathbb{I}$ 2, at http://www.cietac.org.cn/english/arbitrators/arbitrators.htm (2004); see also Arbitration Law art. 13.

295. CPL art. 147. "A litigant contesting a judgment of first instance rendered by a local people's court has the right to appeal to the people's court at the next higher level within 15 days upon the delivery of the court verdict." Id.

296. Arbitration Law art. 9. Article 9 states, "The single ruling system shall be applied in arbitration. The arbitration commission shall not accept any application for arbitration, nor shall a people's court accept any action submitted by the party in respect of the same dispute after an arbitration award has already been given in relation to that matter." Id.

297. Sternberg, supra note 226 , at 39 (mentioning "control" in international arbitration as a way for parties to "privatize certain powers of the judiciary").

298. Winning, supra note 281.

299. Id.; see also Zhong \& Yu, supra note 260 , at 431 . Indeed, local protectionism is "one of the reasons" the Chinese Supreme Court "withdrew jurisdiction over foreign-related commercial cases from all basic and some intermediate courts." Id. at 431 .

300. FRESHFIELDS II, supra note 171, at 11.

301. Famous remark by Deng Xiaoping. See Excerpt from a talk with Susumu Nikaido, Vice-President of the Liberal Democratic Party of Japan (1985), available at http://www.chinadaily.com.cn/english/doc/2004-08/09/content_363585.htm.

302. See FDI Regulations \& Dispute Resolution Mechanisms, supra note 84, at 99.

303. XIANFA art. 5. 
Constitutional amendment is an important step. Indeed, the Constitution makes clear that "[n]o organization or individual may enjoy the privilege of being above the Constitution and the law." 304 However true in practice this might be, ${ }^{305}$ these additions to the Constitution can be seen as an eagerness by China to enter a rule of law state.

\section{A. Legal Reform}

China's WTO accession also provides a strong impetus to amend the national laws and to progress toward a rule of law. ${ }^{306}$ Since there are no specific clauses in the WTO agreement as to how a country should apply the new rules, Cao Jianming, Justice and Vice-President of the Supreme People's Court of the People's Republic of China, ${ }^{307}$ recommends that China adopt a "transformational" approach to the problem of applying the WTO rules to domestic law. ${ }^{308}$ Transformational application requires that the domestic law be revised to comply with WTO regulations. ${ }^{309}$ This would require all departments and local governments to "clear" their existing internal policies and to "abolish and amend" all those regulations that are not in conformity with the WTO. ${ }^{310}$ Further, to respond to the increased "international commercial and political activity, many new laws and regulations should be made."311 Moreover, the SPC has requested that all the courts in China "make public" all their decisions. ${ }^{312}$

304. Id.

305. See Empirical Study of Enforcement, supra note 238, at 307. "[T]here remains a wide gap between the laws on the books and actual practice. To be sure there is a gap in every system" but it is "wider in China." Id.

306. Donald C. Clarke, China's Legal System and the WTO: Prospects for Compliance, 2 WaSh. U. GLOBAL Stud. L. Rev. 97 (2003). By the end of the year 2000, in anticipation of WTO accession, the Ministry of Foreign Trade and Economic Cooperation achieved: the review of over 1400 laws, regulations, and similar documents, including six statutes (of which five were revised), 164 State Council regulations (of which 114 were to be repealed and 25 amended), 887 of its own ministry regulations (of which 459 were to be repealed and 95 amended), 191 bilateral trade agreements, 72 bilateral investment treaties, and 93 tax treaties. In the first two months of 2001, the various ministries and commissions of the State Council reportedly reviewed some 2300 laws and regulations, of which 830 were identified as in need of repeal and 325 as in need of revision.

Id. at 104.

307. See Cao, supra note 75 , at 388.

308. See id. at 379. "The best way for China to apply the WTO agreement during China's period of transition is to amend its national laws or to transform the WTO agreement into national laws." Id. at 380.

309. Id. at 379.

310. See id. at 386.

311. Id. at 381 .

312. Id. at 388. When certain policies were issued, no information was exchanged or published, and foreign-invested enterprises only became "aware of the policy changes until they were faced with a particular problem." Id. at 386. 
China's entry into the WTO can not be viewed simply a means to attract more foreign investment or export more Chinese products, but also as a way to "force through difficult changes in the domestic economic system." ${ }^{\text {,13 }}$ Reasons for this idea may include the difficulty the central government has with supervising the local governments. ${ }^{314}$ The central government has the obligation to ensure that the local governments do not engage in local protectionism by continuing to issue laws inconsistent with the WTO. ${ }^{315}$

Accession to the WTO may be seen as "a central government decision essentially imposed on local governments."316 In addition, the benefits that China derives from the growing economic alliance with the West include the "advancements in Chinese commercial law ... [,] slimmed-down bureaucracies, and adherence to international safety and environmental standards.",317 WTO accession for China means that the economic reforms that benefit investors can be "lock[ed] in" and become "irrevocable." 318 It remains to be seen whether China will fully comply with these ambitious plans, ${ }^{319}$ but they are a step in the right direction.

\section{B. Foreign Investment Law Reform}

It is in the interest of China's central government to implement the WTO reforms and bring the local sectors into compliance in order to increase foreign investor confidence. ${ }^{320}$ In April 2001, due to pressure from the WTO ${ }^{321}$ and

313. Clarke, supra note 306 , at 97 . WTO accession is seen as a part of a "larger strategy of massive and fundamental economic change." Id.; see also Halverson, supra note 9, at 333. WTO accession is seen as "generating necessary momentum to complete the most politically difficult stage of China's move to a market economy." Id.

314. See Empirical Study of Enforcement, supra note 238, at 325. "The Party itself wants to rein in the wayward local governments and ensure that central laws and policies are implemented." ld.

315. See Clarke, supra note 306, at 107.

The main factor behind local economic protectionism is the dependence of local government upon local enterprises for revenue. To the extent a government collects revenues, whether in the form of taxes or profits from an enterprise, it is Id. similar to an owner and has an interest in protecting those revenues.

316. Id. at 98 .

317. George J. Gilboy, The Myth Behind China's Miracle, 83 ForeIGN AFF. 4 (2004), available at http://www.foreignaffairs.org/20040701 faessay83405/george-j-gilboy/the-mythbehind-china-s-miracle.html.

318. Halverson, supra note 9, at 334 (noting that the "WTO framework acts as a sort of constitution" and imposes a standard on the Chinese government).

319. See Empirical Study of Enforcement, supra note 238, at 325-26. The article posits that "entry into WTO will not have an immediate impact" on the "types of rule of law problems that make doing business in China difficult" because "WTO rules assume a government limited by laws and in particular legal limits on executive actions." Id.

320. See Halverson, supra note 9, at 332. "There are obvious reasons why China would view WTO membership as beneficial. China stands to benefit from the recognition and prestige 
other sources, ${ }^{322}$ China further relaxed its attitudes toward WFOEs and made significant changes to the regulations. New regulations relating to FIEs in China are an improvement for the foreign investor. ${ }^{323}$ For example, the "Regulations on Foreign Investment Guidelines," promulgated by the State Council on February 11, 2002, lay out various categories of newly-permitted industries for the investor. ${ }^{324}$ However, the regulations still forbid any investment in the media, including newspapers, movies, and telecommunications. ${ }^{325}$

Several of the most important changes directly affecting the foreign investor include the repeal or modification of the following: the requirement that the WFOE export a certain percentage of its products and advanced technology is no longer required but only discretionary; ${ }^{326}$ the prohibition on the direct sale of products to the domestic market "without government approval;"327 the requirement that all raw materials and fuel be purchased within China unless unobtainable from domestic sources; ${ }^{328}$ that WFOEs must sell products according to China's price control rules; and the restricting of WFOE investment to certain business lines. ${ }^{329}$ Further restrictions on WFOEs (and other FDI vehicles) were scheduled to be lifted on December 11, 2004. ${ }^{330}$

Foreign investors are free to set up wholly foreign owned commercial enterprises (not only production or manufacturing enterprises), and therefore

that WTO membership brings. WTO membership will deepen China's integration into the world economy and signal its status as a world economic power." Id.

321. Peerenboom \& Xu, supra note $90, \S 3.02(1)$.

322. Id. The following are some reasons for the trend towards WFOEs: the "gradual elimination of the discriminatory treatment' of the WFOEs under Chinese law, "competition for foreign investment among local governments," reluctance of foreign investors to transfer technology for fear of intellectual property leaks, and "increased investor sophistication" in dealing with local business practices and customs. Id.

323. See generally FDI Regulations \& Dispute Resolution Mechanisms, supra note 84, at 98-99. The author notes that foreign investment in China is seen as "risky" and "have caused many to question the ability of the Chinese government ... to reform the rather unfriendly FDI environment." Id.

324. JONES DAY, supra note 87.

325. Implementation Regulations for the Wholly Foreign Owned Enterprise Law of the People's Republic of China (Dec. 12, 1990), http://english.ibd.com.cn/news/readcredit.asp?newsid=68. Article 4 states: "No foreign-capital enterprise shall be established in the following trades: (1) the press, publication, broadcasting, television, and movies; (2) domestic commerce, foreign trade, and insurance; (3) post and telecommunications; (4)other trades in which the establishment of foreign-capital enterprises of foreign-capital enterprise is forbidden, as prescribed by Chinese government ." Id.

326. See FDI Regulations \& Dispute Resolution Mechanisms, supra note 84, at 107.

327. Id. at 108 .

328. Id.

329. FDI Laws and Policies, supra note 89 , at 41 . The restricted business lines include: "media, real estate, communications and transportation and public utilities." Id.

330. Julie Walton, WTO: China Enters Year Three, CHINA BUS. REv., http://www.chinabusinessreview.com/public/0401/01.html (n.d.) (last visited Mar. 31, 2006). See also The U.S. ChINA Business CounCIL, Foreign INVESTMENT IN ChINA (Jan. 2006), at http:/www.uschina.org/public/documents/2006/02/foreign-direct-investment-2006.html. In 2006, China is scheduled to open more business sectors to foreign investment. Id. 
the business scope for retail, franchise, and wholesale will be expanded. ${ }^{331}$ The procedures and laws for setting up and operating an enterprise in China are becoming more clear and understandable for the foreign investor and going it alone is much less overwhelming. ${ }^{332}$ These significant changes are a welcome sign that China is dedicated to its WTO commitments and is taking reform seriously.

\section{Dispute Resolution Reform}

It seems that the recent May 2005 reforms to CIETAC aim to increase the perception of fairness during arbitration. Specifically, the 2005 reforms have attempted to eliminate the criticisms regarding CIETAC's perceived conflicts of interest ${ }^{333}$ by requiring arbitrators to "disclose" any "facts or circumstances" that may raise suspicion about the neutrality of the arbitrator. ${ }^{334}$ In addition, the reforms provide an additional option for agreement upon a third arbitrator. ${ }^{335}$ Now, even when the parties are unable to reach an agreement with respect to a third arbitrator, CIETAC now allows each party to submit a separate list of nominees, and if there is "only one common candidate on the list," that person will be the third arbitrator. ${ }^{336}$ And, as mentioned above, "non-panel" arbitrators may now be chosen. ${ }^{337}$ These are important steps in bringing international arbitration in China up to international standards. ${ }^{338}$

In 1995, the Judges Law required that after July 1, 1995, all judges must have a college education and pass a national examination. ${ }^{339}$ Similarly, the Lawyer's Law of 1996 provided that lawyers in China must meet certain

331. Walton, supra note 330.

332. Cao, supra note 75 , at 388 . China's WTO commitment that "all laws, regulations, decisions and administrative policies made . . . by each locality . . . that relate to . . . economic cooperation should be in conformity with national laws and regulations" is being implemented by new unifying laws passed by the National Peoples Congress. Id.

333. See Melnitzer, supra note 218 . The "most common complaint was that CIETAC required parties to appoint arbitrators from [CIETAC's] panel.... [m] easured by the standards of the international arbitration community ... CIETAC still has a ways to go." $l d$.

334. See CIETAC Rules art. 25:

1. An arbitrator appointed by the parties or by the Chairman of the CIETAC shall sign a Declaration and disclose to the CIETAC in writing any facts or circumstances likely to give rise to justifiable doubts as to his/her impartiality or independence. 2. If circumstances that need to be disclosed arise during the arbitral proceedings, the arbitrator shall promptly disclose such circumstances in writing to the CIETAC. 3. The CIETAC shall communicate the Declaration and/or the disclosure to the parties.

Id.

335. See id. art. 22

336. See id.

337. Id. art. 21.

338. See Melnitzer, supra note 218 (noting that these 2005 reforms demonstrate the Chinese authorities "commitment to bringing Chinese arbitration in line with international standards").

339. See Halverson, supra note 9 , at 349. 
professional standards to practice law in China. ${ }^{340}$ Chinese lawyers are no longer defined as "'state legal workers' " and are given a more independent status. ${ }^{341}$ In addition, China is sending many lawyers to the United States and other European countries to be trained to handle "international legal service business" disputes. ${ }^{342}$ In 1992, the Chinese government allowed foreign law firms to set up representative offices in China; however, they still must be registered as "consulting firms," and they may not interpret Chinese law. ${ }^{343}$

The legal industry is still highly regulated by the Chinese government, ${ }^{344}$ but it is partly a result of the need to protect China's "fledgling" legal service industry from more developed competitors. ${ }^{345}$ China's WTO commitments to allow more legal service competition may force China's legal service sector to "improve ... [its] own competence" as the restrictions of foreign law firms are lifted; ${ }^{346}$ a welcome improvement for foreign investors. In addition, efforts have been made to reduce the effects of local protectionism on the court system by proposing different models of reform, ${ }^{347}$ such as "merging high courts of several neighboring provinces" to form a "cross-provincial judicial district court. ${ }^{348}$ All these reforms should make dispute resolution a less forbidding procedure for both the FIE and the foreign enterprise in China.

\section{CONCLUSION}

Can China ever fully implement these reforms while operating under the "dictatorship" 349 that is the current Communist Party? The WTO-compliant

340. See id.; see also Lu, supra note 278 , at 323. Because Chinese lawyers must now have at least a bachelor's degree, the prospects for increasing the education level of lawyers in China "will improve greatly in the next decade." Id.

341. Liu, supra note 276 at 1074 . "The law stresses the need for lawyers to 'pursue independently the practice' under the law, and to exercise a high degree of professionalism and personal ethics." Id.

342. Lu, supra note 278 , at 325 .

343. Jane Heller, Comment, China's New Law Firm Regulations: A Step in the Wrong Direction, 12 PAC. RIM L. \& PoL'Y J. 751,758 (2003).

344. See Lu, supra note 278, at 278.

345. Id. at 318.

346. Id.

347. See generally Vernon Mei-Ying Hung, China's WTO Commitment on Independent Judicial Review: Impact on Legal and Political Reform, 52 AM. J. CoMP. L. 77, 123-132(2004).

348. Id. at 126.

349. XIANFA pmbl. The preamble reads, in part:

Under the leadership of the Communist Party of China and the guidance of Marxism- Leninism and Mao Zedong Thought, the Chinese people of all nationalities will continue to adhere to the people's democratic dictatorship and follow the socialist road, steadily improve socialist institutions, develop socialist democracy, improve the socialist legal system and work hard and self-reliantly to modernize industry, agriculture, national defence and science and technology step by step to turn China into a socialist country with a high level of culture and democracy.

Id. 
economic reforms that have been instituted strongly support the state-owned enterprises, while slowing the rise of an independent private sector. ${ }^{350}$ In addition, the "business risks inherent in China's unreformed political system" cause Chinese businessmen to develop relationships with Communist Party members. ${ }^{351}$ China's political system also continues to be implicated as an impediment to further liberalization of the economy and further advancements in the judicial branch. ${ }^{352}$ And, for the time being, the President of China, $\mathrm{Hu}$ Jintao, does not seem willing to make changes to the current Communist system in China. ${ }^{353}$

However, it must be noted that the Communist Party is rarely to blame for local protectionism. ${ }^{354}$ Most leaders in the central government are more concerned with attracting foreign investment and do not want China's "reputation sullied by negative publicity."355 It is important that China is seen as a "work in progress" and one that has not yet reached the level of other "advanced industrialized economies." 336 Indeed, China's move toward a more law-based state does not necessarily require a "full transition to a Western-style democratic government." ${ }^{\text {"357 }}$ Strengthening the rule of law in China can remain

350. See Gilboy, supra note 317. The Chinese government gives preferential treatment to the SOEs, and the economic reforms favor the foreign investor. As a result, the private sector is "unable to compete with either on equal terms." Id.; see also Ahmad, supra note 11. State owned enterprises (SOE) in China are more concerned with maintaining "patronage and employment than ... generat[ing] profits," and the private businesses remain too small to "offer an effective counterweight to the state sector." Id.

351. Gilboy, supra note 317. This "horizontal association" prevents "long term technology development and diffusion." Id. The result is "technological and economic weakness." Id.

352. Empirical Study of Enforcement, supra note 238, at 286; see also Halverson, supra note 9, at 363. "While China has undergone dramatic economic and even legal changes in the process of joining the WTO, the CCP has endeavored to maintain rigid control over other spheres of Chinese society." Id.

353. What Price Reform?, The ECONOMIST, Sept. 25, 2004, at 53. Mr. Hu, in a speech on September 15,2004, is quoted as saying, "history has proved that in China copying the model of western political systems is a dead-end road." Id.; see also Hu's in Charge, THE ECONOMIST, Aug. 18, 2005, available at http://www.economist.com/world/asia/displayStory.cfm?story_id=4300177. "Mr. Hu has shown no sign of retreat from the core belief of party leaders since the early 1990 s," and he is "widely regarded as a conservative authoritarian." Id.

354. See Empirical Study of Enforcement, supra note 238, at 285. Studies have shown that "government officials are three times as likely to interfere with the courts as the CCP." Id.

355. Id. at 286. In fact, the "Party" is often a valuable ally in the fight against "local protectionism." Id. at 286; see also Ahmad, supra note 11. The Chinese government is "well aware that its political acceptance derives solely from rapid economic growth, and will do whatever is necessary to meet its internal benchmark, an annual rise of 7\%." Id.

356. Gilboy, supra note 317.

357. Orts, supra note 22 , at 86 . "The rule of law in this political and normative sense presumes a corresponding development of a relatively autonomous legal and judicial systemthat is, judges and lawyers who function independently of the government and, in particular, of the Chinese Communist Party." Id. 
a separate goal to power the major shift to a democratic government. ${ }^{358}$ For a developing country like China, perhaps the "prioritization of socioeconomic rights over civilpolitical [sic] rights" is justified because without economic modernization and development, the "citizens will neither enjoy the benefits of the rule of law nor civil-political rights." 359

China remains an attractive location for investment and the future outlook appears bright for the foreign investor. It is undeniable that the institution of communism is an impediment on the path to future reforms, but however constrained, there has been a steady progress toward a rule of law and a more transparent and less perplexing legal system. The reforms to the Chinese legal system as they impact foreign investors are substantial. The nature of these reforms imply that the advancements are not only interim measures, but reflect an institutional change in attitude toward foreign investment. For the foreign investor deciding whether an FIE or a foreign enterprise is the best FDI vehicle, a close scrutiny of the legal implications of each FDI vehicle, the array of laws that can aversely or favorably affect the investor, and an appreciation of the tangle of laws and cultural norms that regulate dispute resolution with Chinese parties are essential starting points. Truly, investing in China involves "patience, patience and more patience," 360 but the rewards for the foreign investor can be glorious. ${ }^{361}$

358. See id. at 87. "Given the historical antipathy toward Western-style democracy in China, it may make sense for Western policymakers, as well as the Chinese themselves, to focus instead on the rule of law as an orienting ideal. Democracy might remain a long-term objective." Id.

359. Killion, supra note 48, at 548. "Prompting China to expediently implement a modern legal system" is like putting the "proverbial cart before the horse." Id. The need for "stability" in China's "fragile infrastructure" calls for a "steady yet gradual approach to modernity." Id. at 550.

360. See Lauchli, supra note 162 , at 1045.

361. "Poverty is not socialism. To get rich is glorious" is a famous saying by Deng Xiaoping. See Thomas Hon Wing Polin \& Tim Healy, Man of the Century, AsIAWEeK (2001), at http://www.asiaweek.com/asiaweek/97/0307/cs6.html. 
